\title{
Colorado Plateau Coring Project, Phase I (CPCP-I): a continuously cored, globally exportable chronology of Triassic continental environmental change from western North America
}

\author{
Paul E. Olsen ${ }^{1}$, John W. Geissman ${ }^{2}$, Dennis V. Kent ${ }^{3,1}$, George E. Gehrels ${ }^{4}$, Roland Mundil ${ }^{5}$, \\ Randall B. Irmis ${ }^{6}$, Christopher Lepre ${ }^{1,3}$, Cornelia Rasmussen ${ }^{6}$, Dominique Giesler ${ }^{4}$, William G. Parker ${ }^{7}$, \\ Natalia Zakharova ${ }^{8,1}$, Wolfram M. Kürschner ${ }^{9}$, Charlotte Miller ${ }^{10}$, Viktoria Baranyi ${ }^{9}$, \\ Morgan F. Schaller ${ }^{11}$, Jessica H. Whiteside ${ }^{12}$, Douglas Schnurrenberger ${ }^{13}$, Anders Noren ${ }^{13}$, \\ Kristina Brady Shannon ${ }^{13}$, Ryan O'Grady ${ }^{13}$, Matthew W. Colbert ${ }^{14}$, Jessie Maisano ${ }^{14}$, David Edey ${ }^{14}$, \\ Sean T. Kinney ${ }^{1}$, Roberto Molina-Garza ${ }^{15}$, Gerhard H. Bachman ${ }^{16}$, Jingeng Sha ${ }^{17}$, and the CPCD team ${ }^{*}$ \\ ${ }^{1}$ Lamont-Doherty Earth Observatory of Columbia University, Palisades, NY 10964, USA \\ ${ }^{2}$ Department of Geosciences, University of Texas at Dallas, Richardson, TX 75080, USA \\ ${ }^{3}$ Earth and Planetary Sciences, Rutgers University, Piscataway, NJ 08854, USA \\ ${ }^{4}$ Department of Geosciences, University of Arizona, Tucson, AZ 85721, USA \\ ${ }^{5}$ Berkeley Geochronology Center, 2455 Ridge Rd., Berkeley CA 94709, USA \\ ${ }^{6}$ Natural History Museum of Utah and Department of Geology \& Geophysics, \\ University of Utah, Salt Lake City, UT 84108, USA \\ ${ }^{7}$ Petrified Forest National Park, Petrified Forest, AZ 86028, USA \\ ${ }^{8}$ Department of Earth and Atmospheric Sciences, Central Michigan University, \\ Mount Pleasant, MI 48859, USA \\ ${ }^{9}$ Department of Geosciences, University of Oslo, P.O. Box 1047, Blindern, Oslo 0316, Norway \\ ${ }^{10}$ MARUM Center for Marine Environmental Sciences, University of Bremen, Bremen, Germany \\ ${ }^{11}$ Earth and Environmental Sciences, Rensselaer Polytechnic Institute (RPI), Troy, NY 12180, USA \\ ${ }^{12}$ National Oceanography Centre, Southampton, University of Southampton, Southampton, SO17 1BJ, UK \\ ${ }^{13}$ Continental Scientific Drilling Coordination Office and LacCore Facility, N.H. Winchell School of Earth \\ Sciences, University of Minnesota, Minneapolis, MN 55455, USA \\ ${ }^{14}$ University of Texas High Resolution X-ray CT Facility, The University of Texas at Austin, \\ Austin, TX 78712, USA \\ ${ }^{15}$ Centro de Geociencias, Universidad Nacional Autónoma de México (UNAM), Boulevard Juriquilla No. \\ 3001, Querétaro 76230, México \\ ${ }^{16}$ Martin-Luther-Universität, Halle-Wittenberg, Institut für Geowissenschaften, Von-Seckendorff-Platz 3, \\ 06120 Halle (Saale), Germany \\ ${ }^{17}$ State Key Laboratory of Palaeobiology and Stratigraphy, Nanjing Institute of Geology and Paleontology and \\ Center for Excellence in Life and Paleoenvironment, Nanjing 210008, China \\ *A full list of authors appears at the end of the paper.
}

Correspondence: Paul E. Olsen (polsen@1deo.columbia.edu)

Received: 17 January 2018 - Revised: 14 July 2018 - Accepted: 3 September 2018 - Published: 22 October 2018

Abstract. Phase 1 of the Colorado Plateau Coring Project (CPCP-I) recovered a total of over $850 \mathrm{~m}$ of stratigraphically overlapping core from three coreholes at two sites in the Early to Middle and Late Triassic age largely fluvial Moenkopi and Chinle formations in Petrified Forest National Park (PFNP), northeastern Arizona, USA. Coring took place during November and December of 2013 and the project is now in its post-drilling 
science phase. The CPCP cores have abundant detrital zircon-producing layers (with survey LA-ICP-MS dates selectively resampled for CA-ID-TIMS U-Pb ages ranging in age from at least 210 to $241 \mathrm{Ma}$ ), which together with their magnetic polarity stratigraphy demonstrate that a globally exportable timescale can be produced from these continental sequences and in the process show that a prominent gap in the calibrated Phanerozoic record can be filled. The portion of core CPCP-PFNP13-1A for which the polarity stratigraphy has been completed thus far spans $\sim 215$ to $209 \mathrm{Ma}$ of the Late Triassic age, and strongly validates the longer Newark-Hartford Astrochronostratigraphic-calibrated magnetic Polarity Time-Scale (APTS) based on cores recovered in the 1990s during the Newark Basin Coring Project (NBCP).

Core recovery was $\sim 100 \%$ in all holes (Table 1 ). The coreholes were inclined $\sim 60-75^{\circ}$ approximately to the south to ensure azimuthal orientation in the nearly flat-lying bedding, critical to the interpretation of paleomagentic polarity stratigraphy. The two longest of the cores (CPCP-PFNP13-1A and 2B) were CT-scanned in their entirety at the University of Texas High Resolution X-ray CT Facility in Austin, TX, and subsequently along with 2A, all cores were split and processed at the CSDCO/LacCore Facility, in Minneapolis, MN, where they were scanned for physical property logs and imaging. While remaining the property of the Federal Government, the archive half of each core is curated at the NSF-sponsored LacCore Core Repository and the working half is stored at the Rutgers University Core Repository in Piscataway, NJ, where the initial sampling party was held in 2015 with several additional sampling events following. Additional planned study will recover the rest of the polarity stratigraphy of the cores as additional zircon ages, sedimentary structure and paleosol facies analysis, stable isotope geochemistry, and calibrated XRF core scanning are accomplished. Together with strategic outcrop studies in Petrified Forest National Park and environs, these cores will allow the vast amount of surface paleontological and paleoenvironmental information recorded in the continental Triassic of western North America to be confidently placed in a secure context along with important events such as the giant Manicouagan impact at $\sim 215.5 \mathrm{Ma}$ (Ramezani et al., 2005) and long wavelength astronomical cycles pacing global environmental change and trends in atmospheric gas composition during the dawn of the dinosaurs.

\section{Context and motivation}

Bracketed between two of the largest mass extinctions, the Triassic Period (ca. 252-202 Ma) saw the evolution of the major elements of modern animal communities on land, had arguably the highest atmospheric $\mathrm{CO}_{2}$ concentrations of the Phanerozoic (Foster et al., 2017) (>4000 ppm: Schaller et al., 2015), and has the longest recovered continuous records of orbitally paced climate change (Olsen and Kent, 1996; Ikeda and Tada, 2014; Kent et al., 2017) - one that bears the fingerprint of the chaotic evolution of the Solar System (Olsen and Kent, 1999; Ikeda and Tada, 2013) (Fig. 1). By the Late Triassic, continental tetrapod associations were remarkably segregated into latitudinal zones, and although dinosaurs had evolved by the beginning of that epoch, herbivorous forms were restricted to high latitudes, while in tropical communities carnivorous dinosaurs remained a relatively minor part of communities, tending also to be rather small (Whiteside et al., 2015). In the oceans, during this time, calcareous nanoplankton made their appearance (Bown et al., 2004), modern reef-forming corals evolved (Stanley, 1981), and archaic forms such as conodonts declined (Tanner et al., 2004).

But despite the pivotal role of the Triassic, the period is characterized by very poor chronologic constraints. This has been especially true for the longest age (stage) of the Triassic, the Norian ( 206-228 Ma), arguably the acme of Triassic life and the longest age of the Phanerozoic. As of 2011, there were only three $\mathrm{U}-\mathrm{Pb}$ zircon dates over the $22 \mathrm{Myr}$ time interval available to constrain the stage (see Olsen et al., 2011), and even its boundary ages and especially marine to continental correlations have remained hotly contested (Muttoni et al., 2004; Ogg et al., 2012). The Late Triassic-Early Jurassic astrochronology and associated paleomagnetic polarity stratigraphy from the largely lacustrine Newark Basin based on cores mostly from the NSF-funded Newark Basin Coring Project (NBCP) completed in the mid-1990s served as the basis of a high-resolution timescale and has been broadly accepted (e.g., Walker et al., 2013; IUGS/ISC, 2017). However, because it was pinned by radioisotopic dates only at the top of the Triassic age section, its accuracy has been questioned from a number of fronts (e.g., Hilgen et al., 1997; Tanner and Lucas, 2015), including largely biostratigraphically based assertions of the presence of cryptic but significant gaps in the upper part of the Triassic age section that would separate the dated levels from 1000s of meters of the underlying section (Gallet et al., 2003; Kozur and Weems, 2005; Tanner et al., 2004).

Progress in past Earth system science fundamentally depended on being able to measure time at appropriate levels of resolution and also being able to link contemporaneous events, fossil occurrences, and environmental records across geography, and this ability has been sorely lacking for many time intervals in Earth's history. To address 


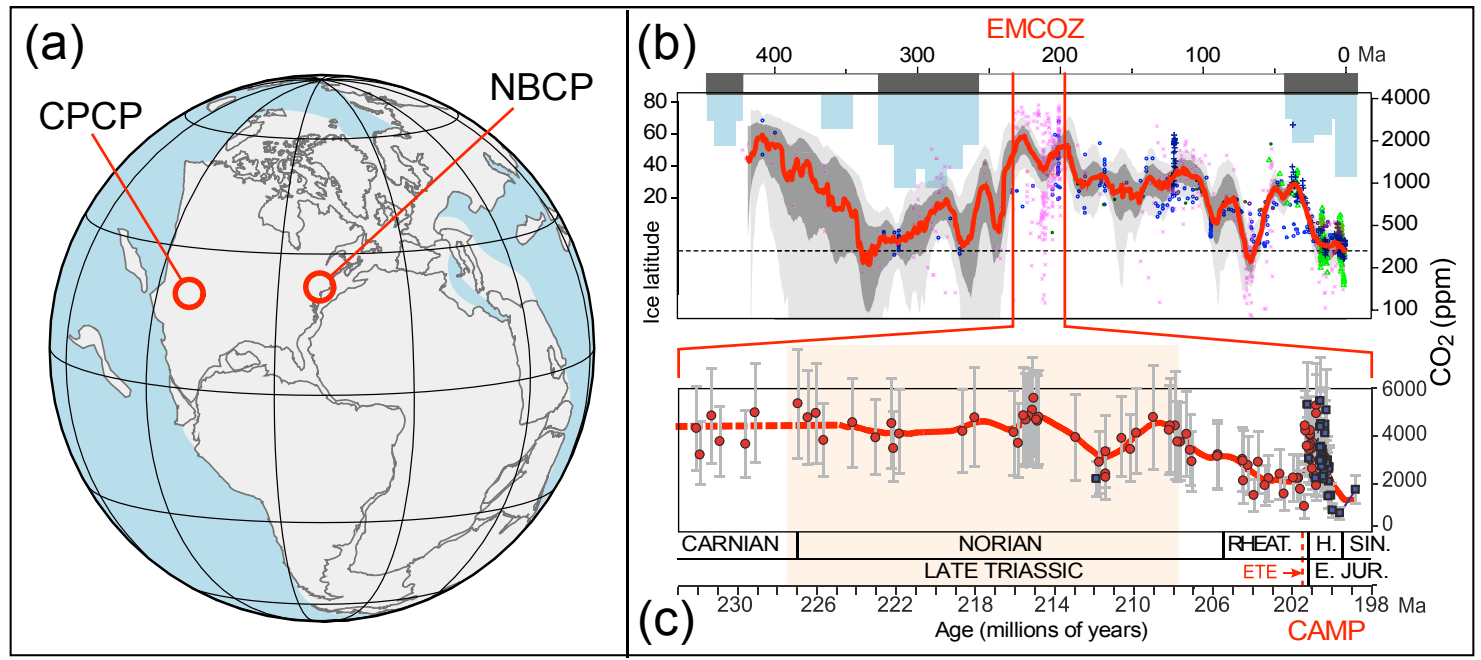

Figure 1. Context for the CPCP cores. (a) Late Triassic-Early Jurassic Pangea showing the positions of CPCP cores and Newark Basin Coring Project (NBCP) APTS (based on Whiteside et al., 2010). (b) Compilation of $\mathrm{CO}_{2}$ proxy data and extent of continental ice modified from Foster et al. (2017) with latitudinal extent of ice (light blue bars) and ice-house conditions (grey bars). Proxy symbols are leaf stomata, blue open circles; pedogenic carbonate, pink crosses; boron isotopes, green triangles; liverworts, blue filled circles; and alkenones, blue

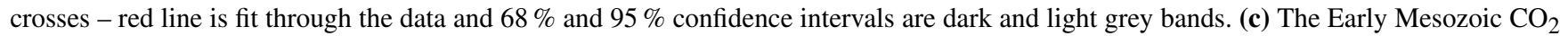
Zenith (EMCOZ), based on the pedogenic $\mathrm{CO}_{2}$ proxy from the Newark and Hartford basins, modified from Schaller et al. (2015): red circles are from the Newark Basin and blue circles are from the Hartford Basin; light orange area is interval encompassed by the Chinle Formation in CPCP cores; red line is the smoothed fit through the data; and the dashed red line mean for the points without astrochronologic time control.

this cross-cutting issue for the Triassic, we launched the Colorado Plateau Coring Project (CPCP) as an interdisciplinary multiphase coring experiment in a geologic setting where there was sufficient background information to know there would be abundant zircon U-Pb datable deposits and a recoverable paleomagnetic polarity record that together would allow for a meaningful, globally exportable timescale. Also, deemed highly desirable, would be the selection of a target where cores would leverage, and allow for correlation with, a large amount of previously collected surface information. The CPCP was an outcome of the 1999 US NSF- and ICDP-funded "International Workshop for a Climatic, Biotic, and Tectonic, Pole-to-Pole Coring Transect of Triassic-Jurassic Pangea" (http://www.ldeo.columbia. edu/ polsen/nbcp/westpangea.html, last access: September 2018) that recognized "Western Equatorial Pangea (Colorado Plateau)" as a key coring target. Subsequent CPCP workshops held in 2007 and 2009 (funded by the US NSF, ICDP, and DOSECC) narrowed down the optimal site for the first phase of the CPCP to Petrified Forest National Park, in northern Arizona (Fig. 2) (Olsen et al., 2008; Geissman et al., 2010; http://www.ldeo.columbia.edu/ polsen/ cpcp/CPCP_home_page_general.html, last access: September 2018), where strata of the ?Early-Middle Triassic age Moenkopi Formation and Late Triassic Chinle Formation are well represented and have been comparatively very well studied in previous projects, some of which demonstrated that zircon $\mathrm{U}-\mathrm{Pb}$ geochronologic information (Riggs et al.,
2003) and paleomagnetic polarity stratigraphies (Steiner and Lucas, 2000; Zeigler et al., 2017) could be recovered. Furthermore, long-term study (Parker and Martz, 2011) of the superb exposures of Petrified Forest National Park (PFNP) had resulted by that time in a well-characterized physical stratigraphy (Woody, 2006; Martz and Parker, 2010; Martz et al., 2012), into which rich assemblages of vertebrates (Long and Murry, 1995; Parker and Irmis, 2005) and plants (Ash, 1972, 1989; Fisher and Dunay, 1984; Litwin, 1991), and their environments (Therrien and Fastovsky, 2000) were registered (Parker, 2006). These outcrops also have the best record of what is arguably the most prominent continental biotic transition of the Late Triassic (prior to the end Triassic extinction), the Adamanian-Revueltian Biozone boundary (Parker and Martz, 2011; Martz and Parker, 2017) that seems plausibly linked to the great Manicouagan bolide impact (Ramezani et al., 2005; Parker and Martz, 2011; Olsen et al., 2011). Proposals were submitted in 2010 and funding was secured from both the US NSF and ICDP by 2013 to recover a continuous cored record of the Triassic record in PFNP. The CPCP, Phase I scientific coring experiment designed to explicitly test competing Triassic stratigraphic, temporal, climatic and biotic hypotheses took place during November and December of that same year, and involved drilling at northern and southern locations in Petrified Forest National Park (Figs. 2, $4)$. 


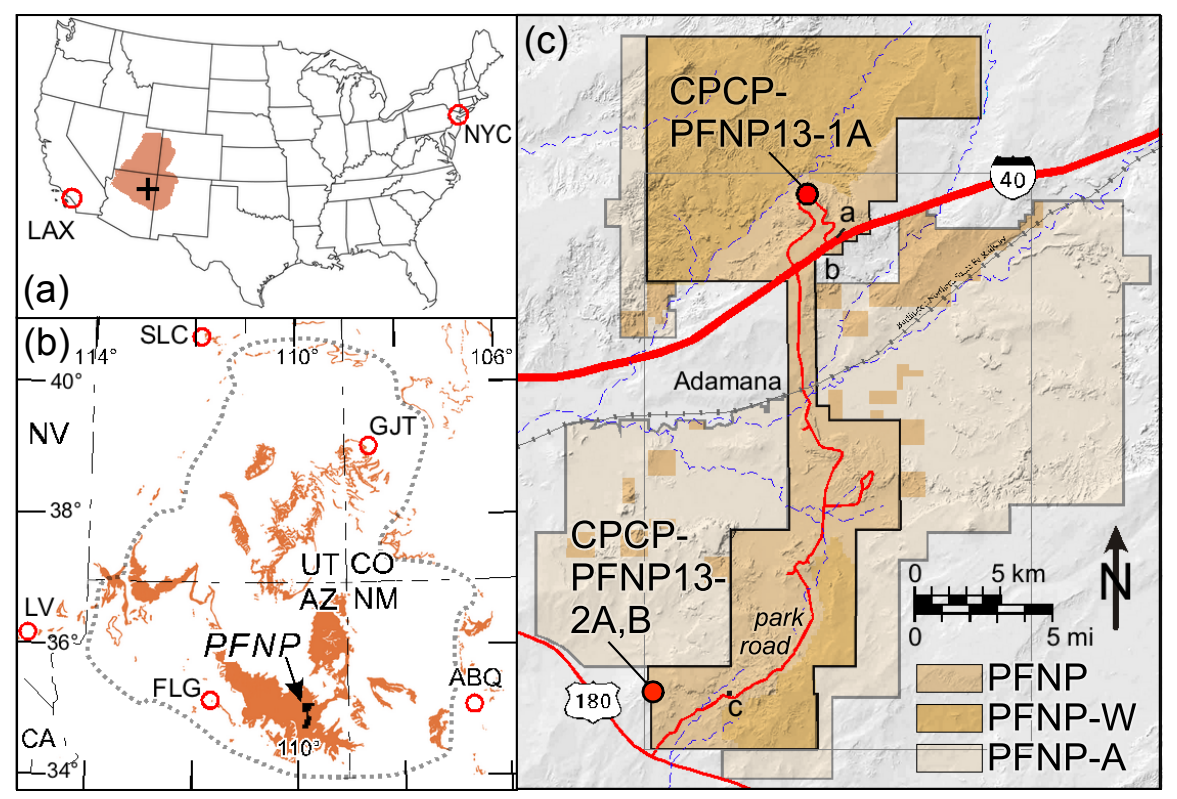

Figure 2. Location of CPCP cores. (a) Location of the Colorado Plateau (red-brown area) in the United States with the cross marking the location of the coring sites in Petrified Forest National Park: LAX, Los Angeles, California; NYC, New York City, New York, which is just to the east and south of the location of the Newark-Hartford APTS (NBCP cores and outcrops). (b) outline of the Colorado Plateau (dotted line) and Triassic outcrop area (red brown) showing the location of Petrified Forest National Park (PFNP): ABQ, Albuquerque, New Mexico (NM); FLG, Flagstaff, Arizona (AZ); GJT, Grand Junction, Colorado (CO); LV, Las Vegas, Nevada (NV); SLC, Salt Lake City, Utah (UT); CA, California. (c) Map of PFNP with location of the coring sites: PFNP, Petrified Forest National Park; PFNP-A, Private or State Trust land; PFNP-W, Petrified Forest National Park, Wilderness area; a, park headquarters; b, park entrance off I-40; c, Rainbow Forest Museum; PFNP-CPCP13-1A, core site at Chinde Point; PFNP-CPCP13-2A, 2B, core site at "West Bone Yard".

\subsection{The need to core}

Despite the superb outcrops of Triassic strata in parts of the American Southwest, a scientific drilling experiment was essential because most continuous sections in outcrop are either inaccessible in vertical cliffs or are weathered and geochemically altered, making observations and sampling at the appropriate level of detail impossible. Furthermore, the characteristic shallow bedding attitudes in combination with lateral facies changes typical of these largely fluvial systems compromise the ability to determine superposition in sections compiled over long geographic distances. This is especially clear at PFNP, where there are two main outcrop areas, a northern area with the stratigraphically higher parts of the sections and a southern area with the stratigraphically lower Chinle sections. These outcrop areas are separated by about $20 \mathrm{~km}$ of no exposure; although the sections have been individually quite well studied, no two analyses of the combined stratigraphic column published in 20 years agreed, some compilations differing by as much as $30 \%$ in total thickness. Additionally, the lowermost parts of the Chinle Formation and underlying Triassic Moenkopi Formation do not crop out in the park. The situation is worse in other areas of the American Southwest.

\subsection{Tectonic environment}

The overall tectonic context of early Mesozoic strata in the American Southwest is uncertain, because, compared to the relatively simple Triassic-Jurassic extension and continental rifting of central Pangea, including eastern Laurentia, models of the western North American Cordillera are complex, involving exotic terranes, magmatic arcs, oceanic-plate subduction, and intense crustal deformation lasting until the early Cenozoic, with most of the pertinent tectonic geometry being so strongly deformed as to be inferable only by indirect means. Since the 1970 s the leading hypothesis for the tectonic context of the mostly continental Triassic-Jurassic sequences was that they developed during eastwardly directed oceanic-crust subduction of the Farallon Plate beneath North America with a magmatic (Cordilleran) arc over the subducting slab and west of the backarc, back-bulge, backarc tectonic furrow, or foreland retroarc basins in which the Triassic-Jurassic deposits accumulated (Burchfiel and Davis, 1972; Lawton, 1994; Gehrels et al., 2000; Barth and Wooden, 2006; Sigloch and Mihalynuk, 2017; Dickinson, 2018) (Fig. 3). An alternative and controversial model based on geologic and geophysical (tomographic) data postulates that western North America was a passive continental margin from the Paleozoic until the Cretaceous with westward- 
(a)
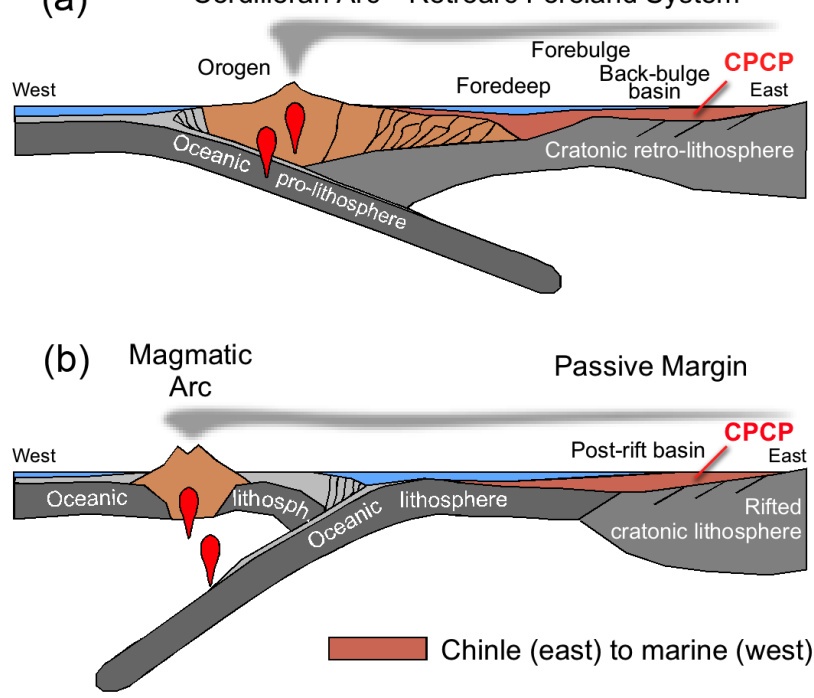

Figure 3. Generalized cartoons of end-members of the alternative tectonic models for the Chinle basin (at position of CPCP in red). (a) Conventional model of a Triassic Cordilleran arc with a retroarc basin with Chinle and marine strata (modified and generalized from Eriksson et al., 2008; DeCelles and Giles, 1996). (b) Passive margin model for Triassic western North America (modified from Chemenda et al., 1997) which is consistent with Hildebrand (2013). Note that realistic, empirically based cross sections for these end-member models have yet to be published and that these are cartoons based on possible analog situations, with the additional caveat that the significant possibility of large strike-slip components (nonplane strain) is not addressed in this figure. Note also that Chinle was probably in a belt of easterly (trade) winds at the time.

dipping subduction (Hildebrand, 2009; Sigloch and Mihalynuk, 2013). Despite the extreme differences, both models are consistent with having most of the sediment of the Triassic-Jurassic sequences derived from northwesterly flowing fluvial systems, with a persistent slope from the interior of Pangea as well as closer topographic remnants of the Ancestral Rocky Mountain orogen, toward the Cordilleran margin (Riggs et al., 1996). The sources of the fluvial and eolian transport systems during the Triassic-Jurassic time have been documented using detrital zircons (Dickinson and Gehrels, 2008a, b). In both eastward and westward subduction models a southwestern source of silicic volcanic debris is generally identified with the postulated Cordilleran arc or Mogollan Highlands (Howell and Blakey, 2013; Riggs et al., 2013, 2016; Dickinson, 2018). Although the active margin, backarc-retroarc models have basin depocenters and syndepositional deformation localized by proximal active compressive and flexural forces of the approaching arc, or slabrelated dynamic subsidence, there is ample evidence that much local deformation and localized subsidence was controlled by early Mesozoic halokenesis (salt tectonics) (Shoemaker et al., 1958; Hazel, 1994; Matthews et al., 2007;
Trudgill, 2011; Banham and Mountney, 2014; Hartley and Evenstar, 2017) that might, in fact, prove more important than either basement-involved tectonics or eustasy in structuring much of the stratigraphy (P. E. Olsen et al., 2016). An additional, generally overlooked consideration is that the southern and eastern edges of the western US TriassicJurassic sequences lie against the projection of the Central Atlantic rift system, and changes in the uplift of the northwestern rift shoulders related to extensional pulses are plausible factors in modulating rates of supply of sediments to the deposits of the American Southwest (Huber et al., 2016).

The more recent history and origin of the Colorado Plateau itself remains somewhat enigmatic and debated as well, with useful recent reviews of the history being Flowers (2010) and Liu and Gurnis (2010). The plateau is characterized by relatively undeformed crust and is almost entirely surrounded by strongly shortened and subsequently highly extended regions. Apparently prior to and after the Late Cretaceous to early Cenozoic formation of the Central and Southern Rocky Mountains, the region was relatively low-lying, but during the medial Cenozoic extension that formed the Basin and Range physiographic province to the west and the Rio Grande rift to the east, the plateau was uplifted by at least a kilometer and originally east-flowing streams and rivers that deeply incised parts of the plateau and reversed their course, resulting in the more modern version of the Grand Canyon of the Colorado River and associated erosional features. The combined effects of the shortening and extension was a clockwise rotation of the Colorado Plateau about a vertical axis of perhaps up to a net $\sim 10^{\circ}$ (see Hamilton, 1981; Steiner, 1986; Kent and Witte, 1993; Bryan and Gordon, 1986; Steiner and Lucas, 2000; Wawrzyniec et al., 2002; McCall and Kodama, 2014). In the late Neogene and Quaternary localized mafic volcanism has taken place, indicating ongoing tectonic evolution of the plateau with the geodynamic origin and timing of the events shaping the plateau remaining hotly debated.

\subsection{Climatic context and stratigraphy}

In the broadest sense, the stratigraphic sequence on and close to the plateau remained continental to marginal marine through its entire early Mesozoic history. The Colorado Plateau part of Laurentia was near the Equator in the Early Triassic, moved north through the Triassic from more humid latitudes $\sim 7^{\circ}$ at $220 \mathrm{Ma}$ into arid tropics at $\sim 16^{\circ}$ around $200 \mathrm{Ma}$ (close to the Triassic-Jurassic boundary), continued into the arid sub-tropics at $\sim 27^{\circ}$ through the rest of the Early and Middle Jurassic, and then moved into the temperate latitudes $\sim 47^{\circ}$ by $\sim 150-140 \mathrm{Ma}$ (and the Jurassic-Cretaceous boundary) and remained approximately at this latitude for nearly $100 \mathrm{Myr}$ (e.g., Kent and Irving, 2010). The plateau and surroundings then moved south to the present latitude of $\sim 37^{\circ}$ (Fig. 4). Apart from the Moenkopi Formation, which remains anomalous in being so "arid-looking" despite being 


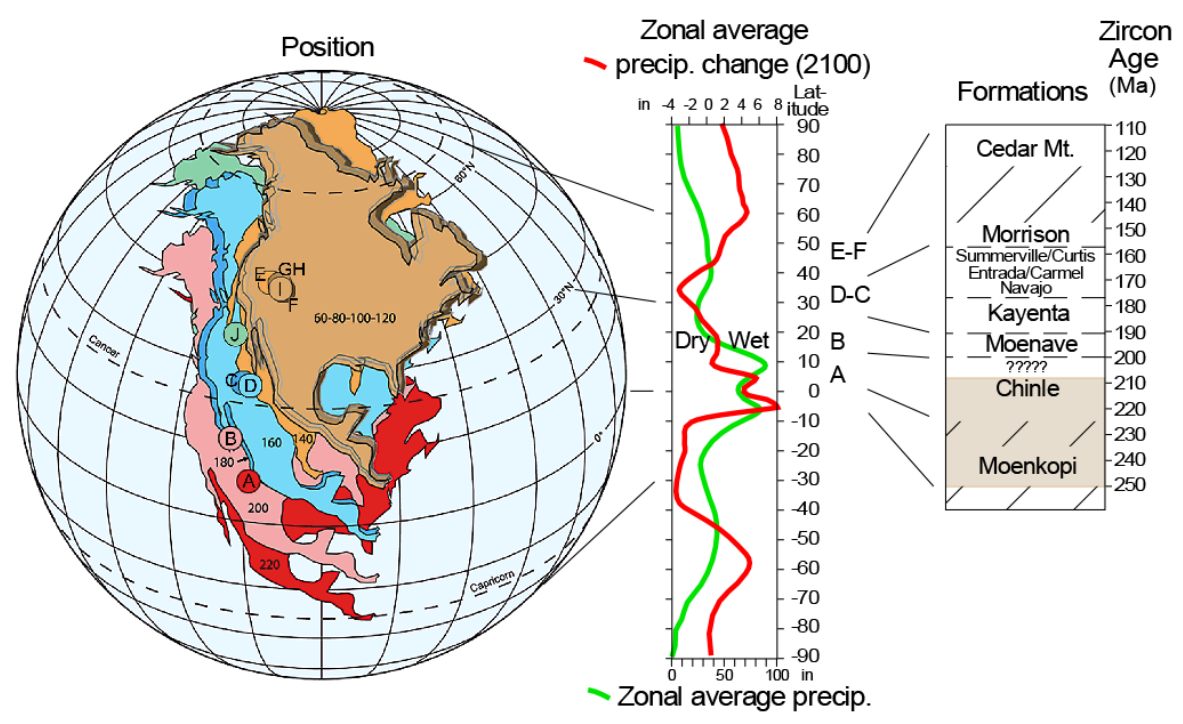

Figure 4. Position of North America (from Kent and Irving, 2010) and the Colorado Plateau (circles) from 220 Ma to Present with comparison to zonally averaged precipitation for today (1950-2000, from https://www.gfdl.noaa.gov/will-the-wet-get-wetter-and-the-dry-drier/, last access: September 2018), change in precipitation for 2100 (ibid.), and the zircon ages for formations (from core CPCP-PFNP13-1A for the Moenkopi and Chinle formations; Suarez et al., 2017 for the Moenave Formation; Marsh et al., 2014 for the Kayenta Formation; Trujillo et al., 2014 for the Morrison Formation; and Mori, 2009 for the Cedar Mountain Formation), with the interval spanned by the CPCP-PNF13 cores shown in $\tan$ (hachures indicate hiatuses). This shows how relatively small northward translation of western North America during the Triassic could result in strong changes in climate sensitive facies.

deposited at or near the Equator, the Late Triassic though Cretaceous climate-sensitive sedimentary facies all track latitude, assuming a simple zonal climate (e.g., Kent and Tauxe, 2005), with the giant sand sea of the Early to ?Middle Jurassic age Navajo Sandstone deposited in the subtropics near $30^{\circ} \mathrm{N}$, and much less arid facies developing during Late Jurassic and Early Cretaceous times (Fig. 2).

Although characterized by overall very high $p \mathrm{CO}_{2}$, there are a number of significant fluctuations documented for the Late Triassic (Fig. 2) and Early Jurassic (Schaller et al., 2011, 2015). Although apparently not related to the overall trend in Colorado Plateau climate-sensitive facies, these would be expected to have global change consequences that should be recognizable once the latitudinal shift in the North American Plate is accounted for. At least one of these shifts in the late Norian (Fig. 2) should have been encountered in the CPCP cores.

The oldest Triassic age strata in the PFNP area are part of the nominally Early to Middle Triassic age Moenkopi Formation, its age having been inferred using marine fossils found in distant areas to the west and local tetrapod biostratigraphy (Morales, 1987; Lucas and Schoch, 2002). There are, however, no fossils known from very low in the formation, and therefore its base could conceivably be as old as Late Permian or considerably younger, its top could be as young as early Late Triassic (Carnian) based on admittedly sparse available geochronology (Dickinson and Gehrels, 2009). The Moenkopi could also be of different ages in different areas of the plateau and surroundings. One of the goals of the CPCP is to better constrain the age of these important, paleo-tropical vertebrate assemblages by independent, non-biostratigraphic means.

Most of the rest of Triassic time in the Colorado Plateau is recorded by the continental, largely fluvial Chinle Formation, of which the oldest dated strata are early Norian in age (Olsen et al., 2011; Ramezani et al., 2011) and the youngest late-, but perhaps not latest-Rhaetian in age. The Chinle Formation has provided one of the richest Pangean tropical plant and vertebrate assemblages of Norian and Rhaetian age in the world. In addition, recent advances based on inspection of outcrops have demonstrated that $\mathrm{U}-\mathrm{Pb}$ detrital zircon geochronology (Ramezani et al., 2011, 2014) provides effective and accurate time control. Putting these outcrop studies in a context where superposition is undoubted, and directly registered to the geochronologic data was another goal of the CPCP.

\section{Scientific goals and questions}

Based on discussions during the 2007 and 2009 CPCP workshops and preparation for the 2010 proposals, a series of principal guiding questions were recognized. Workshop participants concluded these questions could be best addressed by the environmental and U-Pb calibrated magnetic polarity stratigraphic records of a PFNP core experiment. The questions included the following. 
1. Is the Newark Basin astrochronostratigraphic polarity timescale (APTS) for the Late Triassic consistent with independent radioisotopic dates and magnetic polarity stratigraphy from the Chinle Formation?

2. Were marine and continental biotic turnover events in the Triassic synchronous? Specifically, as the apparent largest magnitude faunal turnover event on land during the Late Triassic (Mid-Norian, Adamanian-Revueltian boundary) synchronous with the giant Manicouagan bolide impact, independent of it, or an artefact of a condensed section or hiatus, and does it correlate with the marine turnover?

3. There is an apparent pattern of latitudinal biotic provinciality reported in the Late Triassic. Is it supported by high-resolution independent (i.e., non-biostratigraphic) correlations, and is that provinciality correlated with climate-related environmental proxies?

4. Is the orbitally paced (Milankovitch) cyclical climate change recorded in the Newark basin lacustrine facies reflected in the largely fluvial Chinle and Moenkopi formations?

5. Do $\mathrm{CO}_{2}$ proxies in the western US track those from the eastern US, and how do they relate to the records of environmental change seen in the cores and other areas?

\section{Drilling summary}

The overall drilling plan was formulated and PFNP was selected as the coring location for Phase One of the project during the 2009 CPCP Workshop at the New Mexico Museum of Natural History and Science in Albuquerque, New Mexico (Geissman et al., 2010). After funding from ICDP was approved in 2010, and from NSF in 2013, the first (Chinde Point) of two specific coring sites was finalized in June and August 2013 after two visits to PFNP to meet with park personnel, representatives of the drilling contractor, and the drilling project manager (D. Schnurrenberger) (Figs. 5 and 6; Table 1). Less than 2 weeks into the coring of the Chinde Point hole, at a depth of over $400 \mathrm{~m}$, it was clear that core recovery through most of the Triassic sequence was excellent and progressing at a rapid and very successful rate. It quickly became clear that we would finish ahead of schedule and under budget. Consequently, we requested a small amount of additional funding from ICDP to leverage our setup to core a second site, which was approved in late November (Figs. 5 and 6; Table 1). The rational for a second coring site in the southern part of the park was that it would allow us to assess the lateral variation and completeness in physical and paleomagnetic polarity stratigraphy. Site 2 selection commenced immediately and set up and coring at site $2 \mathrm{~A}$ began on 26 November 2013 (Fig. 5), with the planned total depth of core 


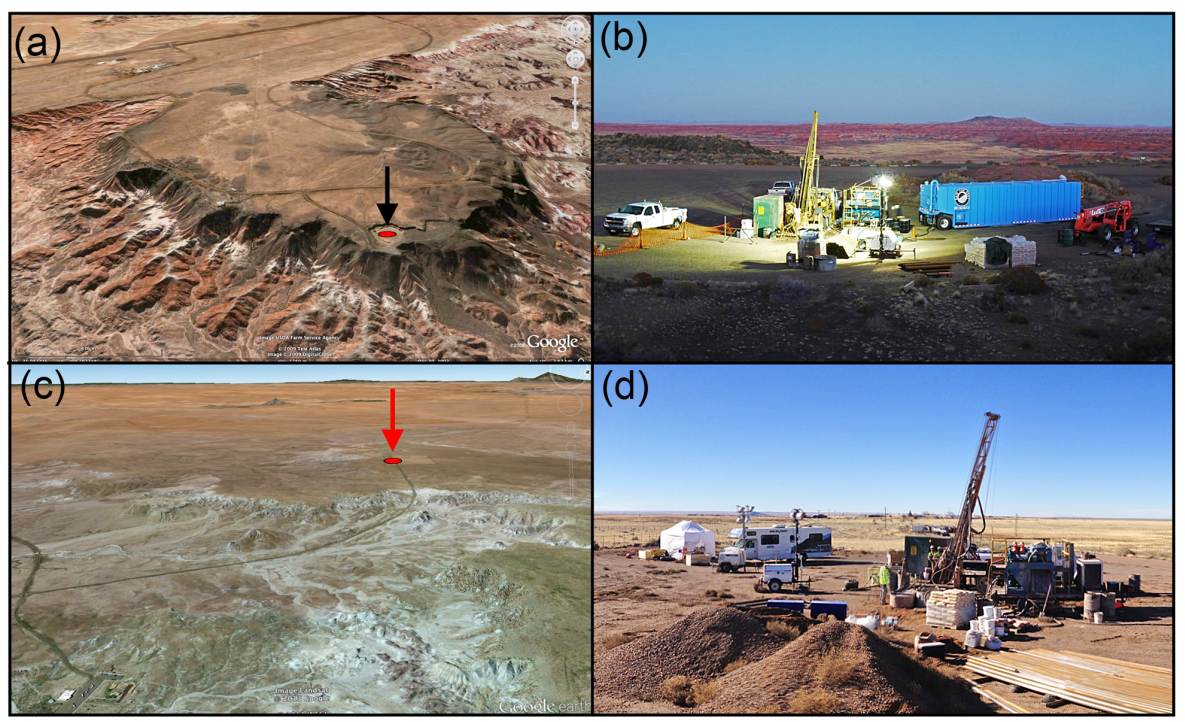

Figure 5. CPCP coring sites: (a) Chinde Point (GoogleEarth image) looking south with CPCP-PFNP13-1A coring site in the foreground (red dot and arrow) on mesa capped by Bidahochi Formation lava and lake strata overlying basal Owl Rock Member and Petrified Forest Member of the Chinle Formation with the prominent white band being the ash-rich Black Forest Bed of the upper Petrified Forest Member - Park Headquarters is at upper left; (b) CPCP-PFNP13-1A coring site at Chinde Point, looking north at dusk, during coring; (c) "West Bone Yard" (GoogleEarth image) site of CPCP-PFNP13-2A and -2B (red dot and arrow) looking west - hills in the distance are Hopi Buttes Bidahochi Formation mares and buildings in the foreground; left are parts of the Rainbow Forest Museum; (d) CPCP-PFNP13-2B site at "West Bone Yard" during coring, looking west.

1A (bottoming in Early Permian age Coconino Sandstone) having been reached on 24 November 2013. Site 2A was terminated on December 2 because of problems with hole collapse, and the rig was moved over about $4 \mathrm{~m}$ and coring at site 2B commenced on 2 December and total depth was reached on 7 December 2013 (again bottoming in Early Permian age Coconino Sandstone) (Table 1). The additional core processing and associated science for these two additional cores required a supplement from NSF that was approved in December 2015.

Ruen Drilling, Inc. was the coring operator, having also been the operator for the Bighorn Basin Coring Project (BBCP) in very similar lithologies (Clyde et al., 2013). As was the case for the BBCP, a truck-mounted Atlas Copco CS1500 wireline diamond coring rig, with HQ3 tooling was used to recover the cores $(6.1 \mathrm{~cm}$ diameter $)$ in polycarbonate liners. Liners were used because of the extremely crumbly nature of the Chinle mudstones that have long been known to have a high expanding clay component of probable volcanic origin (e.g., Allen, 1930; Schultz, 1963). As coring proceeded it became obvious that without liners, recovery in the mudstones (comprising a large proportion of the section) would have been substantially reduced and/or disrupted by drilling and core handling, rendering such cores much less useful for high-resolution analyses and scans. Drilling fluids were water, with minimal additives similar to those used by the BBCP (for core BBCP-PCB11-2B), specifically bentonite powder, polymer, and soda ash due to the necessity of an inclined corehole to avoid rod damage and hole collapse (core hole PFNP13-2A was in fact abandoned because of hole collapse). An AMC Solids Removal Unit centrifuge extracted the cuttings from the drilling fluid during drilling, allowing fluid recycling and cuttings disposal off-site.

Core handling and documentation were led by D. Schnurrenberger and members of the NSF LacCore/CSDCO facility (K. Brady and R. O'Grady), who served as a drillingscience liaison ("company representative") while working on opposite shifts and with support of the science team. After coring, the holes were logged by Century Wireline Services (CWS) (Fig. 5). Down-hole logs were taken to virtually the bottom of holes $1 \mathrm{~A}$ and $2 \mathrm{~B}$, and included magnetic susceptibility, natural gamma ray, resistivity, spontaneous potential, acoustic borehole imaging, and dipmeter surveys, the latter of which are consistent with the Reflex EZ Shot survey data, used to track orientation of the hole during drilling. After logging the holes were filled with heavyweight mud and sealed with cement near the surface.

Because the paleomagnetic polarity stratigraphy of the cores was an essential part of the project, core azimuthal orientation was critical, and we employed three strategies towards that end. First, because bedding is nearly flat in PFNP, the core holes were planned to deviate from vertical, inclining $60^{\circ}$ or $75^{\circ}$ to the SE or SSW depending on the core (Table 1). Inspired by Baag and Helsley (1974) in core recovered from the Moenkopi Formation of Colorado, this allows bedding, or some physical proxy of bedding, to serve for core 


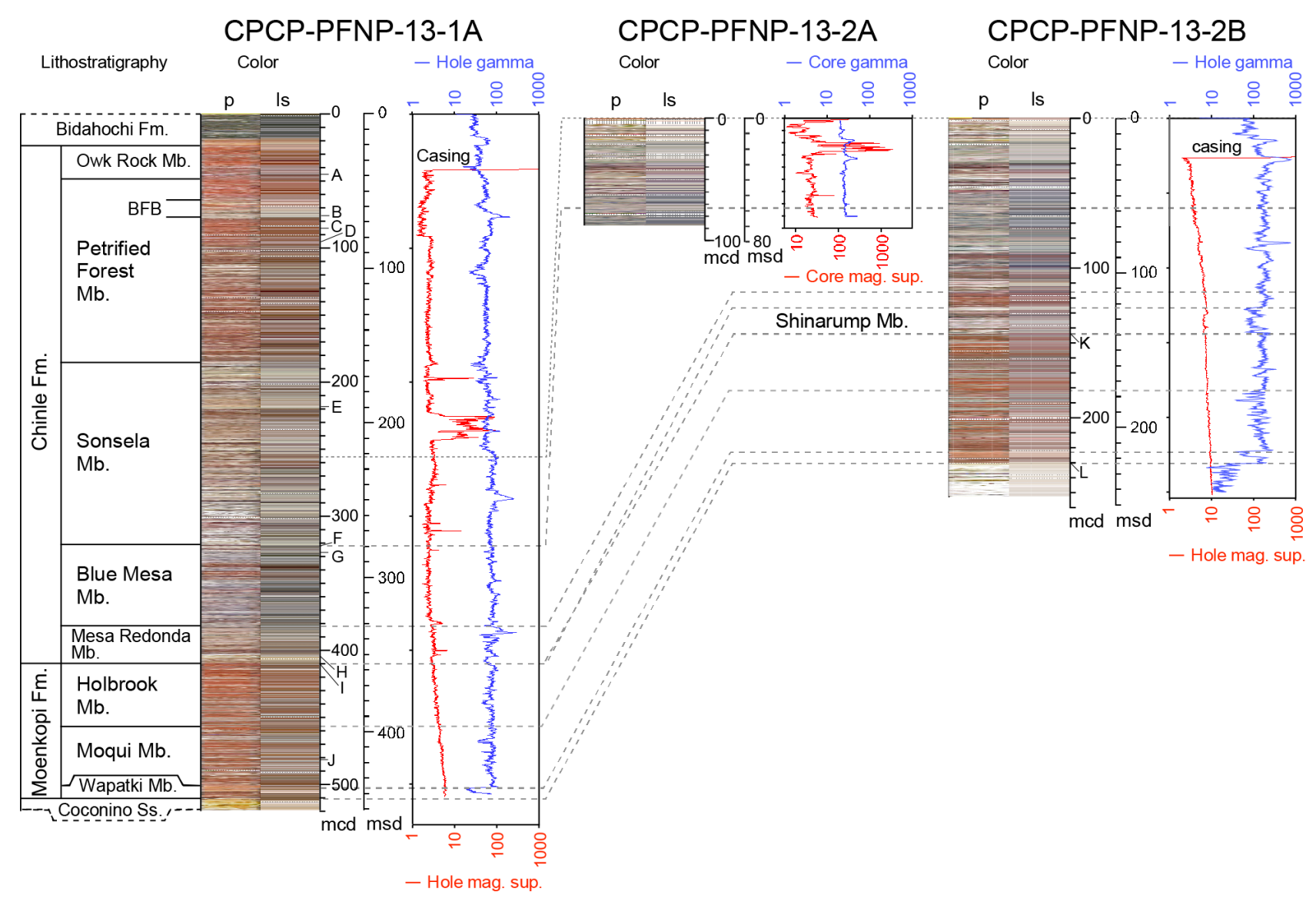

Figure 6. Lithologic logs, compressed photographs (p), line-scan images (ls), natural gamma, and magnetic susceptibility, for each of the cores and holes drilled during the CPCP. Letters A-K refer to core segment photographs in Fig. 8. Abbreviations for the core depths are mcd, meters core (or hole) depth; msd, meters stratigraphic depth of a core or hole with $\mathrm{msd}=0.866 \cdot \mathrm{mcd}$ in $1 \mathrm{~A}, \mathrm{msd}=0.858 \cdot \mathrm{mcd}$ in $2 \mathrm{~A}$, and $\operatorname{msd}=0.969 \cdot \operatorname{mcd}$ in $2 \mathrm{~B}$.

orientation (Fig. 7). This was necessary because during the Triassic the Colorado Plateau was at low latitudes as indicated by paleomagnetic inclinations being close to horizontal (e.g., Molina-Garza et al., 1991) meaning that the polarity could not be assessed from inclination values alone. Second, core orientation was tracked using a REFLEX ACT II/III tool that employs an accelerometer to record the core orientation, with the down side of the inclined hole being marked on the bottom core surface after each run based on the device's data. That mark was then extended to the core liner as a white line marked down the entire length of the liner (or core). A similar tool was used at the Hominin Sites and Paleolakes Drilling Project (HSPDP) (Cohen et al., 2016). Third, after drilling ended, cores $1 \mathrm{~A}$ and $2 \mathrm{~B}$ were CT-scanned in their entirety at the University of Texas at Austin's CT-Scanning US NSF Facility (Fig. 8), to assure that we would have images to check bedding, which we could not see through the transparent plastic liners because of the opacity of the drilling mud, colored by the red beds. These scans will also provide a wealth of three-dimensional sedimentologic details other- wise not visible (Fig. 8). The nominally $1.5 \mathrm{~m}$ core runs were cut on site into roughly $0.7 \mathrm{~m}$ (actual average of $71 \mathrm{~cm}$ ) segments so that they would fit into the CT-Scanner (not to exceed $76.2 \mathrm{~cm}$ ). The up/down orientation of the core segments is maintained with blue endcaps on tops and red endcaps on bottoms of liners, hand-drawn arrows marked on the plastic tube pointing up-core, and T (top) and B (bottom) labels near the endcaps.

The PNFP cores were labeled and cataloged in the field by Schnurrenberger, Brady, and O'Grady, with support from the science team, and were named using the LacCore convention, which is an extension of the IODP and ICDP syntax. For this project, the naming convention is as follows, using CPCP-PFNP13-1A as an example: CPCP, is the expedition name (Colorado Plateau Coring Project); PFNP, is the overall location (Petrified Forest National Park); 13, is the year drilled (2013); 1, is the coring site (site 1, at Chinde Point); and $\mathrm{A}$, is the hole at site (in this case only 1 hole). The cut core segments are labeled continuing with the LacCore protocol, for example for CPCP-PFNP13-2B-108Y-1-A: 108, is 


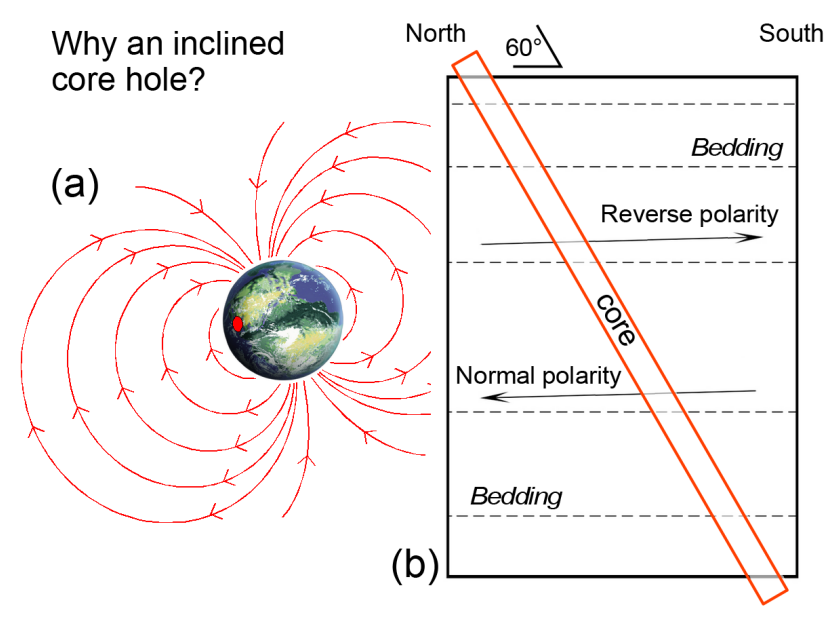

Figure 7. The nearly horizontal bedding in PFNP was used for orientation by inclining the corehole nominally $60^{\circ}$ for $1 \mathrm{~A}$ and $2 \mathrm{~A}$ and $75^{\circ}$ in approximate southerly directions (see Table 1). (a) Earth's magnetic field line (normal polarity) with Earth with Triassic Pangea and location of Colorado Plateau (red dot) - note the field lines near horizontal near the Equator. (b) Diagram of inclined core hole at $60^{\circ}$ with normal and reverse polarity field lines near horizontal due to low latitude position of the Colorado Plateau during the Triassic. The cores were intended to be split along the perpendicular to the inclined core so that bedding is seen to dip $30^{\circ}$, for $1 \mathrm{~A}$ and $2 \mathrm{~A}$, or $15^{\circ}$ for $2 \mathrm{~B}$, relative to the long axis of the core (compare with Fig. 8).

the core barrel run (run 108); $\mathrm{Y}$, is the code for the coring tool used; 1 , is the core segment (uppermost segment cut off the core run); and $\mathrm{A}$, is the designation of the archive half (with $\mathrm{W}$, designating the working half. This code applies to all of digital descriptive data as well (e.g., digital photographs).

\subsection{Site 1: Chinde Point}

Chinde Point, in the northern part of the PFNP (Fig. 5; Table 1), was selected as the main site (for CPCP-PFNP13-1A) because the zircon U-Pb dated Black Forest Bed (Riggs et al., 2003; Ramezani et al., 2011) outcrops directly adjacent to the site providing an important fiducial, and it allows for coring the highest stratigraphic level in the Chinle Formation accessible using a truck-mounted rig. The location picked also consists of an easily accessible parking lot in the floor of an old barrow pit that could be drilled into thus minimizing disturbance - a key consideration of the Park. Total depth was $519.9 \mathrm{~m}$ yielding a total stratigraphic depth of $451 \mathrm{~m}$ (Table 1).

Chinde Point is on the northern edge of a mesa capped by Miocene ( 8.7-6 Ma) "middle" Bidahochi basalt flows of the Hopi Buttes volcanic complex (White, 1990), into which core 1A was spudded. The basalt is underlain by "lower" Bidahochi gypsiferous Neogene (Miocene) lacustrine pale red mudrock, which locally overlies the Triassic age section. The knowledge that there is a remnant of a possible
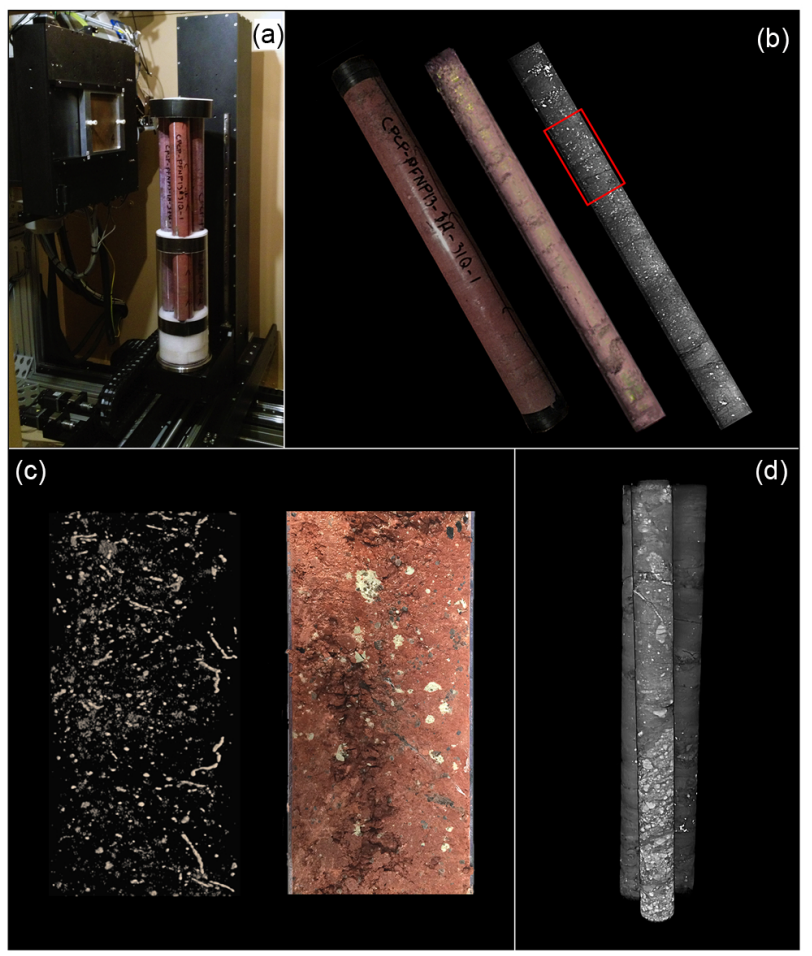

Figure 8. CT scans of CPCP-PFNP13-1A core: (a) three core segments bundled with aluminum rod at center in the $450 \mathrm{kV}$ GE Titan $\mathrm{X}$-ray source and Perkin Elmer flat-panel detector at the University of Texas High Resolution X-ray CT Facility, Austin, TX - visible in the front is CPCP-PFNP13-A1-31Q-1 (cores are approximately $0.7 \mathrm{~m}$ long); (b) four images of core segment CPCP-PFNP13-A1$31 \mathrm{Q}-1$ at core depths 37.5 to $38.2 \mathrm{~m}$ is equivalent to 32.5 to $33.1 \mathrm{~m}$ stratigraphic depth in the basal Owl Rock Member of the Chinle Formation (left image is in visible light with core in its liner, middle image is a colorized CT volume with liner digitally stripped off; right image is a CT volume with an addition $2 \mathrm{~mm}$ stripped off to digitally clean off drilling mud - red box is interval shown in c); (c) enlargement of CT volume shown in red box in (b), left image is CT volume filtered to highlight carbonate-rich rhizoliths (root traces) and right image is digital photograph of the same interval in the slabbed core (core is $\sim 6.35 \mathrm{~cm}$ in diameter) (see https:// www.youtube.com/watch?v=T05S7R7dP7M, last access: September 2018); (d) bundle of three core segments of Owl Rock Member of the Chinle Formation from CT animation of CPCPPFNP13-1A-25Q2 (foreground); CPCP-PFNP13-1A-26Q2; CPCPPFNP13-1A-27Q1 with CPCP-PFNP13-1A-25Q2 volume showing conglomerate and clear bedding inclined to left (cores are approximately $0.7 \mathrm{~m}$ long) (see https://www.youtube.com/watch? $\mathrm{v}=$ ynM-H8_Qu7A\&feature=youtu.be, last access: September 2018).

vent (Ouimette, 1992) on the northwestern side of the mesa only $700 \mathrm{~m}$ southwest from the drill site, and that the vent and lavas might be the remnants of a maar with associated faults, stocks, and phreatic breccias, prompted us to select an azimuth of $\sim 135^{\circ}$ (Table 1) as opposed to due south, which would be more nearly optimal from a paleomagnetic perspec- 
tive. Fortunately, no such features were intersected by the core, and there is no obvious magnetic overprint of Miocene age (Kent et al., 2018), and therefore we conclude the strata recovered in this core were minimally affected by the Neogene igneous activity.

Triassic rocks encountered in PFNP13-1A comprised $335 \mathrm{~m}$ of Late Triassic (Norian) Chinle Formation mudstones, sandstones, and conglomerates that overlie $88 \mathrm{~m}$ of nominally Early and Middle Triassic age Moenkopi Formation. The hole reached a total depth of $451.0 \mathrm{~m}$ after penetrating $7 \mathrm{~m}$ of Early Permian age Coconino Sandstone (Fig. 6: Table 3) (in stratigraphic thickness all rounded to the nearest meter). The recovered core represents the first time both the lower and upper parts of the Chinle Formation, as can be seen in the area of the PFNP, can be inspected and sampled in undoubted superposition.

\subsection{Site 2: West Bone Yard}

To leverage the new information from coring at Chinde Point, site 2 was selected to be in the southern part of the park, about $30.6 \mathrm{~km}$ from site 1. Initially, we had hoped to site it about $2 \mathrm{~km}$ farther to the east, which would have been at a higher stratigraphic position; however, the weather conditions did not permit the drilling truck and support equipment to access that area. Instead we drilled in an equipment storage area called the "West Bone Yard", again minimizing additional disturbance. Unlike the Chinde Point site, bedrock drilling commenced immediately in Triassic strata. Two cores were acquired at site 2: CPCP-PFNP13-2A and CPCP-PFNP132B. Our intention was to again core at an inclination of about $60^{\circ}$. However, coring of PFNP-2A (inclined at $\sim 60^{\circ}$ ) was terminated at a total depth of $81 \mathrm{~m}$ (69 m stratigraphic depth) because of hole collapse, and we decided to site PFNP13$2 \mathrm{~B}$ about $3 \mathrm{~m}$ to the west and drill at an inclination of about $75^{\circ}$ for the entire hole (Table 1). Far fewer problems were encountered coring PFNP13-2B and total depth was reached at about $253 \mathrm{~m}$, comprising about $245 \mathrm{~m}$ of stratigraphic section (Table 1). Despite the shortness of core PFNP13-2A, it duplicates the upper part of the Chinle in PFNP13-2B and thus provides a useful replicate, complementing the minor core loss in both cores.

Core PFNP13-2B spans more than one-quarter of the section recovered at Chinde Point (a total of about $144 \mathrm{~m}$ ), but it is invaluable because it is adjacent to the most data-rich parts of the park sequence. Approximately $87 \mathrm{~m}$ of the Moenkopi Formation was cored along with $22 \mathrm{~m}$ of Coconino Sandstone. Therefore, data from core PFNHP13-2B will permit clear calibration of the fidelity and completeness of the lower Chinle and Moenkopi sections.

\section{Core analysis and initial post-drilling science}

From PFNP, the cores were shipped to The University of Texas at Austin High-Resolution X-ray Computed Tomog- raphy Facility (UTCT). There the cores were scanned on the high-energy subsystem of the North Star Imaging scanner. This subsystem employs a $450 \mathrm{kV}$ GE Titan X-ray source and a Perkin Elmer flat-panel detector. These data were acquired at $355 \mathrm{kV}$ and $1.5 \mathrm{~mA}$, and four brass X-ray prefilters were employed. The detectors were binned $2 \times 2$, resulting in a voxel size of $0.1825 \mathrm{~mm}$. Depending on the length of the core segments, the scanning protocol used helical or cone-beam acquisition or a combination of the two; most core segments required the latter, with resulting volumes digitally stitched together. The core segments were scanned in groups of three, with an aluminum rod placed between them to reduce $\mathrm{CT}$ artifacts and provide a greyscale calibration standard (Fig. 8). All cores were labeled with aluminum tags stamped with the core identifiers, and affixed to indicate coring orientation. The final data volume comprises $394 \mathrm{CT}$ data sets ranging from 299 to 433016 bit TIFF slices.

After CT scanning the cores were shipped to the LacCore facility at the University of Minnesota for Initial Core Description (ICD). Facility staff passed the cores through a Geotek MSCL-S multisensor core logger, for standard parameters: magnetic susceptibility, gamma density, P-wave velocity, electrical resistivity, and natural gamma radiation. Cores were subsequently split in half lengthwise with a rock saw plumbed for continuous deionized water flush (no recirculation) and cleaned. One-half of each core was photographed with a Geotek MSCL-CIS optical linescan camera at 50 micron resolution, and then logged on a Geotek MSCL$\mathrm{XYZ}$ split-core multisensor logger for high-resolution magnetic susceptibility and color reflectance spectrophotometry. Visual lithologic core descriptions were generated by project staff using PSICAT software and modified FGDC standard vocabularies for lithologies, with petrographic smear slide analysis, SEM-EDS, and XRD analyses as needed for component identification. A subset of core archive halves (Petrified Forest and upper Sonsela members) were scanned using an ITRAX XRF Core Scanner for elemental distributions. Scanning of the rest of the cores is anticipated during 2018. The cores remain the property of the US Federal Government (with PEFO (PFNP) catalog numbers: core 1A is PEFO 39602; core 2A is PEFO 39603; core 2B is PEFO 39604); the cores are on long-term loan with all archive halves permanently curated at the LacCore/CSDCO core repository and working halves curated at the Rutgers University Core Repository for subsampling, and additional detailed descriptions.

The LacCore/CSDCO facility coordinates access to core archive halves and fundamental data; Rutgers University coordinates access to core work halves for subsampling. Fundamental datasets include core metadata, multisensor logger data, core photographs, lithologic core descriptions, XRF elemental scans, and derived products such as color profiles and stratigraphic columns. Depth scales were standardized by LacCore/CSDCO, using scaled meters below surface (ap- 
plying a linear compression/scaling where recovery is above $100 \%$ ), equivalent to the CSF-B depth scale used in IODP.

The initial sampling party for core $1 \mathrm{~A}$ was held on 17-20 April 2015 at the Rutgers Core Repository with samples being taken for paleomagnetic analysis, U-Pb geochronology, carbon isotope stratigraphy and soil carbonate $\mathrm{CO}_{2}$ proxy, palynology and organic geochemistry (compound-specific $\mathrm{C}$ isotopes, $\delta^{13} \mathrm{C}_{\mathrm{wax}}$ ), by the lead National Science Foundation PIs and their coworkers along with several additional scientists. Individual teams have sampled and will continue to sample core $1 \mathrm{~A}$ as needed. Sampling parties for cores $2 \mathrm{~A}$ and $2 \mathrm{~B}$, recently processed by at UTCT and LacCore (funded by a supplement from NSF), took place during spring 2018.

\section{Initial results}

A basic result evident from the stratigraphy of core PFNP13$1 \mathrm{~A}$ is that the major discrepancies between the stratigraphy and thickness estimates of Chinle Formation sections in Petrified Forest National Park, as reported by various workers due to the large geographic distances between outcrops where superposition cannot be demonstrated, can now be resolved. The stratigraphy and thicknesses of the major members in core 1A (Fig. 6) closely approximate those of Martz and Parker (2010), Ramezani et al. (2011), and Atchley et al. (2013) and are dramatically different from those depicted by Billingsley (1985), Murry (1990), Steiner and Lucas (2000), and Heckert and Lucas (2002). It can thus serve as a standard lithostratigraphic reference for most of the Late Triassic age continental rocks of the Colorado Plateau. In terms of depositional environments, the Chinle strata in the cores are almost entirely comprised of muddy fluvial paleosols and coarser fluvial channel deposits (Fig. 9).

Overall, there is perhaps a surprising degree of agreement in the lateral consistency of facies between the $1 \mathrm{~A}$ and $2 \mathrm{~B}$ cores as evident in the geophysical logs, especially natural gamma (Fig. 6). There is variability between the alternations of mudstone and sandstone in the Sonsela Member, but nonetheless, details of log character persist across the $\sim 31 \mathrm{~km}$ separating the cores. There are also negligible thickness differences between the lower Chinle strata in the cores, despite the change in facies in the basal-most part of the formation. Supposedly, the conglomeritic facies of the basal Chinle Formation, traditionally referred to as the Shinarump Member, occupies incised valleys in the underlying Moenkopi, but that is not at all evident in core 2B, which contains that conglomerate (clasts up to medium cobble size), and $1 \mathrm{~A}$, which does not and the Shinarump is simply replaced by finer-grained facies of the Mesa Redondo Member lying directly on top of the Moenkopi Formation (Fig. 9). The Moenkopi Formation itself is nearly exactly the same thickness in core $1 \mathrm{~A}$ and $2 \mathrm{~B}$, and also shows a strong similar consistency in the log properties of the members of the formation, most notably in the Moqui Member (Fig. 5).
However, there is a major consequential difference between the outcrops in the park and what is seen in the cores. There is a complete absence of facies resembling the Newspaper Rock Sandstone and attendant low-energy well-bedded mudstones and siltstones in all the cores. These strata comprise large, sandstone, meandering channel complexes up to $10 \mathrm{~m}$ thick with large-scale greenish lateral accretion sets making up scroll bars (ridge-and-swale topography) visible in satellite images. The lateral accretion sandstones have basal lags with abundant fossil wood and plant impressions, and there are associated lacustrine deposits (Trendell et al., 2013) that yield a diverse aquatic fauna and macro- and micro-flora (Daugherty, 1941; Miller and Ash, 1988; Ash, 1989, 2005; Murry and Long, 1989; Demko, 1995; Heckert, 2004; Parker, 2006; Parker et al., 2006a). Very similar facies have been described at various areas of outcrop of the Chinle Formation and have been collectively termed the "Monitor Butte facies", ascribed to incised valleys (Demko et al., 1998). These facies only outcrop locally even in the park and in most areas it they are represented by a laterally continuous red band of pedogenically modified strata about $1 \mathrm{~m}$ thick. However, in several areas outside the park such "incised valleys" appear related to underlying halokinesis of Paleozoic salt (Matthews et al., 2007; P. E. Olsen et al., 2016). Such strata are often characterized by extraordinarily fast accumulation rates as evidenced by the burial of in situ plants, including trees (Parker et al., 2006b; Trendell et al., 2013) implying rates of several meters in a few years (Fig. 10), which would be highly problematic for interpreting paleomagnetic polarity sequences, had this facies occurred in the cores. The southern part of the PFNP in fact lies directly on the center of the thick evaporites of the Holbrook Basin (Rauzi, 2000), making halokinesis a plausible cause of localized development of the Monitor Butte-Newspaper Rock facies.

Outcrops of the Chinle Formation at Petrified Forest National Park have provided much of the basis for our understanding of the palynostratigraphy of the American Southwest Late Triassic (Gottesfeld, 1972; Scott, 1982; Fisher and Dunay, 1984; Litwin et al., 1991; Reichgelt, et al., 2013; Whiteside et al., 2015; Lindström et al., 2016). In total, 258 samples were collected from core CPCP-PFNP13-1A for palynological, bulk $\mathrm{C}$-isotope, and $\delta^{13} \mathrm{C}_{\mathrm{wax}}$. Of these about thirty samples were processed at the University of Oslo and all were barren of recognizable sporomorphs, although very dark, degraded woody or cuticle-like plant fragments are present, consistent with recalcitrant soil organic matter in paleosols (Fig. 11). The prevalence of red and purple paleosols and the lack of "Newspaper Rock-Monitor Butte facies" are at least partially responsible for the near lack of organically preserved plant macrofossils and sporomorphs from the core. Samples were processed for organic geochemistry at Utrecht University (NL) following the methods outlined in Miller et al. (2017). Results indicate very low concentrations of $n$ alkanes which did not have the odd-over-even carbon prefer- 


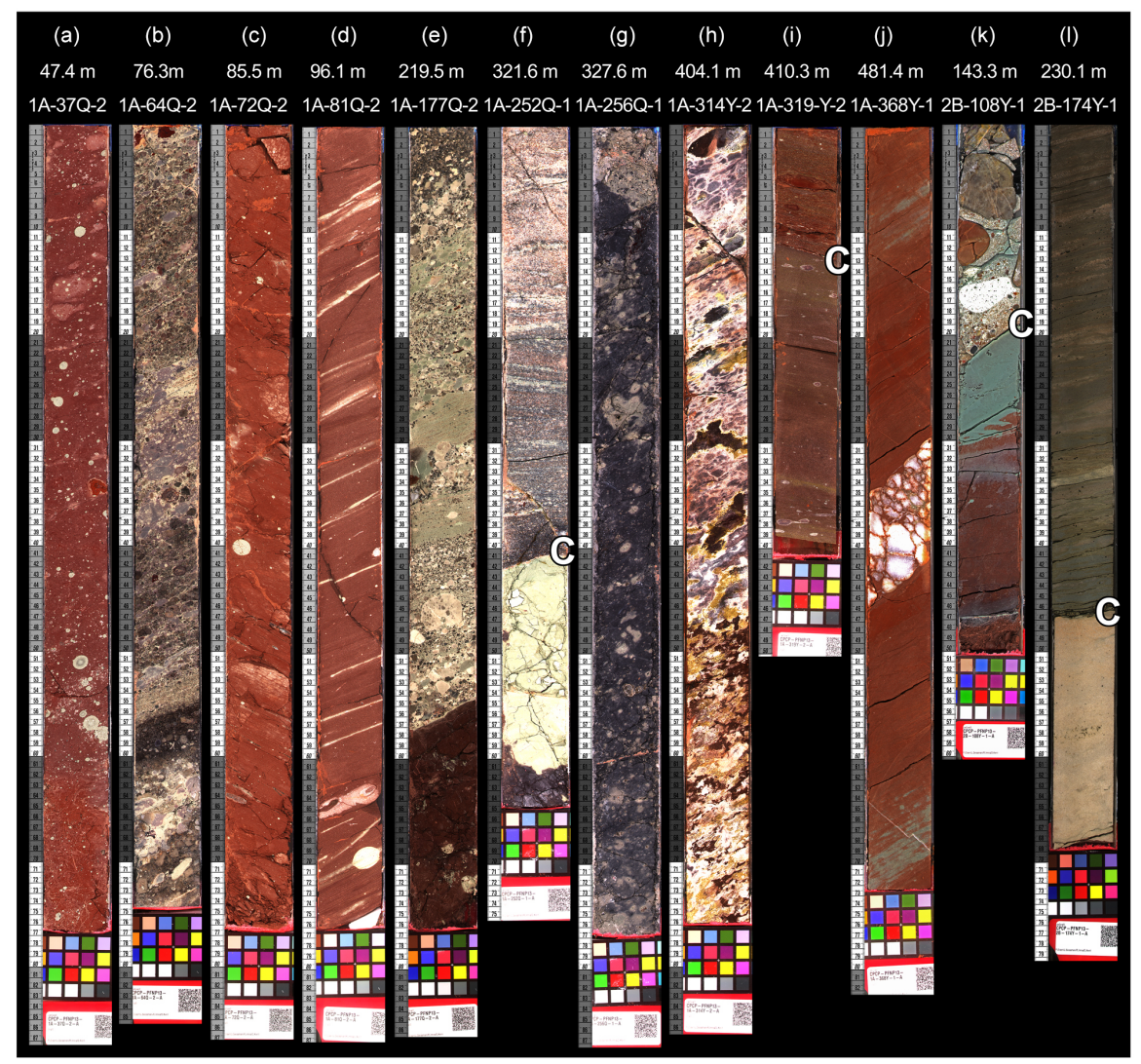

Figure 9. Representative facies in core segments from cores CPCP-PFNP-13-1A (a-j) and CPCP-PFNP-13-2B (k-l) with bedding dipping down towards left except as noted (see Fig. 5): (a) pedogenic mudstone of lower Owl Rock Member of the Chinle Formation in which bedding is obscure but indicated by long axes of elliptical spots ("reduction spots or haloes"); (b) lower Black Forest Bed of the Petrified Forest Member of the Chinle Formation with abundant intraformational carbonate clasts and volcaniclastic material; (c) pedogenic mudstone of the Petrified Forest Member of the Chinle Formation with long axis of elliptical spots inclined downward to the right indicating a misoriented core segment; (d) pedogenic ripple-bedded fine sandstone and siltstone of the Petrified Forest Member of the Chinle Formation with long axes of elliptical spots clearly aligned with bedding; (e) sandstone and conglomerate overlying pedogenic mudstone within the upper Sonsela Member of the Chinle Formation; (f) Contact $\mathrm{C}$ between coarse sandstone of the overlying Sonsela Member of the Chinle Formation and the underlying Blue Mesa Member of the Chinle Formation; (g) pedogenic mudstone of the Blue Mesa Member of the Chinle Formation; (h) four-color mottled pedogenic mudstone of the Mesa Redondo Member of the Chinle Formation; (i) Contact C between sandstone of the overlying Mesa Redondo Member of the Chinle Formation and sandstone and siltstone of the underlying Holbrook Member of the Moenkopi Formation (core segment appears misoriented); (j) chicken-wire gypsum bed in siltstone of the Moqui Member of the Moenkopi Formation; (k) Contact $\mathrm{C}$ between cobble conglomerate of the overlying Shinarump Member of the Chinle Formation and sandstone and siltstone of the underlying Holbrook Member of the Moenkopi Formation; (l) Contact $\mathrm{C}$ between sandstone of the overlying Wupatki Member of the Moenkopi Formation and sandstone of the underlying Coconino Sandstone of Early Permian age.

ence typical of waxes derived from vascular plants as can be seen in rocks of comparable age elsewhere (Fig. 12) (Whiteside et al., 2010). These results are unsurprising in as much as the samples also lacked sporomorphs and well-preserved cuticles. The extracted $n$-alkanes may be indigenous, sourced from pedogenic bacteria or fungi, or the result of biomass burning (e.g., Kuhn et al., 2010; Eckmeier and Wiesenberg, 2009). They could also be natural migrated hydrocarbons. Hydrocarbon shows have been reported in drill holes in the region around PFNP, presumably derived from marginally mature, marine sources rocks in the underlying Paleozoic age
Holbrook Basin (Heylmun, 1997; Rauzi, 2000; Schwab et al., 2017). Furthermore, there is also a remote possibility of an $n$-alkane contribution from drilling fluid additives, although their effect should be minimal because of standard sample preparation protocols. The lack of $n$-alkanes derived from higher plants and the very low concentrations of indigenous organic matter within the samples meant that further organic geochemical, bulk $\mathrm{C}$ isotope and sporomorph, studies were not pursued by WMK, CM, and VB. Nevertheless, additional work on the organic petrology and geochemistry is planned by others. 


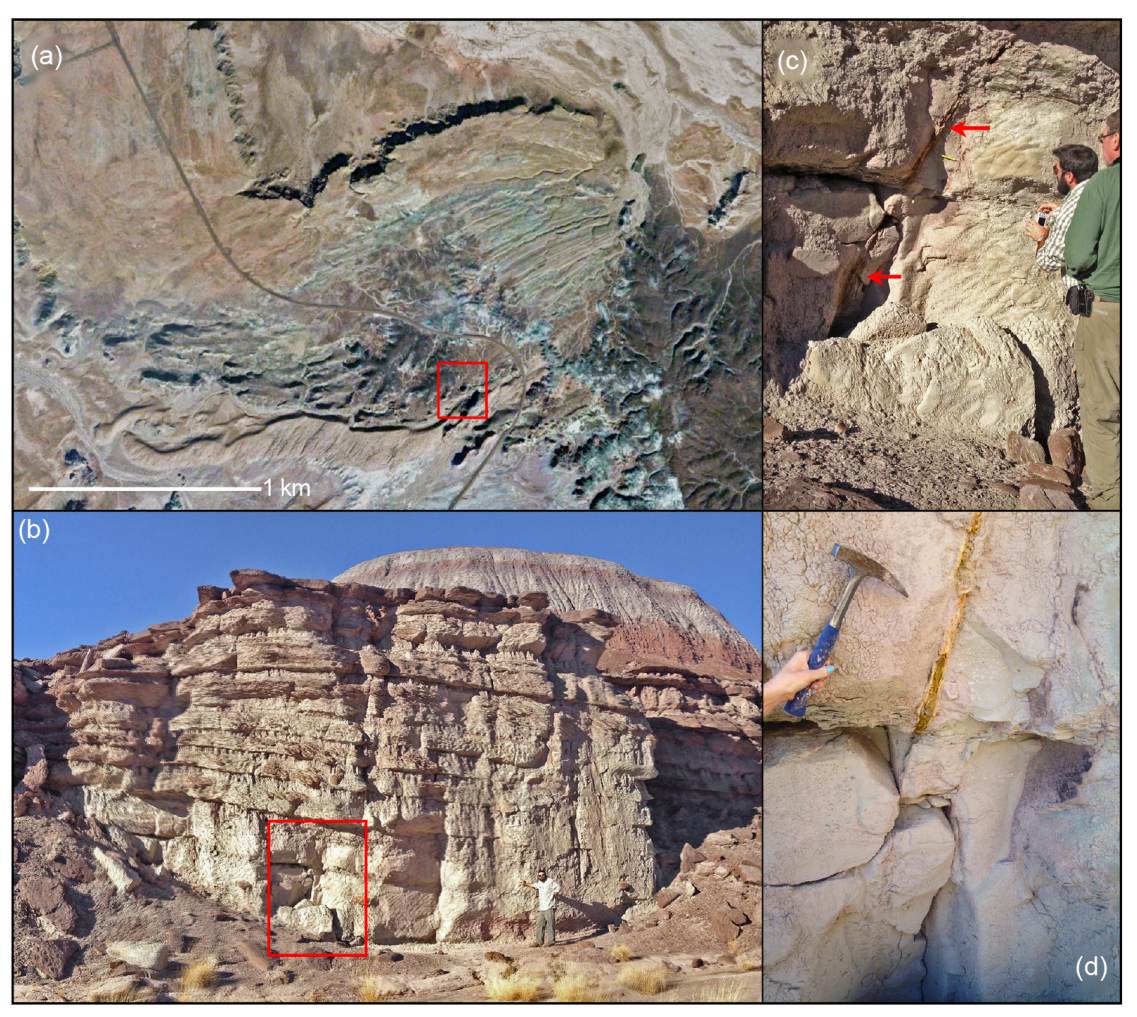

Figure 10. Details of Newspaper Rock facies which is absent in cores: (a) GoogleEarth image of scrollbars (best developed in middle of image), red box is location of photo in (b); (b) tilted beds of greenish ripple-crosslaminated sandstone and siltstones looking north at scrollbar (point bar) at $34.949^{\circ},-109.776^{\circ}$ with $+2 \mathrm{~m}$ upright, plant stem (?Equisetities) in growth position in red box enlarged in (c) indicative of extremely fast accumulation ( $\sim 1 \mathrm{~m} /$ season) - Morgan Schaller for scale; (c) plant stem (?Equisetities) in growth position (portion between arrows) is enlarged in (d) - beds dip from right (west) to left (east) with faint left-inclined streaks being aligned lee faces of climbing ripples; (d) close up of stem in growth position, hammer is $28 \mathrm{~cm}$ long - yellow color is due to weathered pyrite.

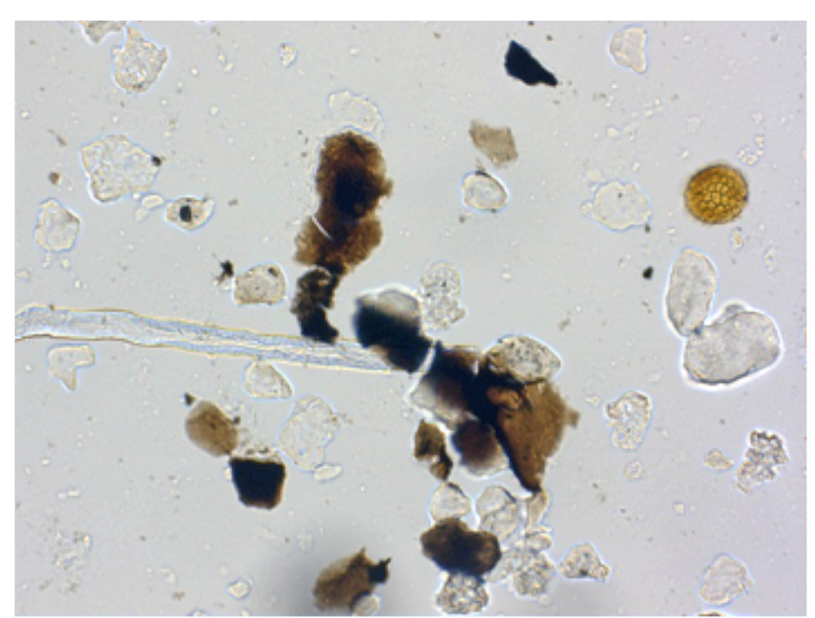

Figure 11. Photograph showing organic residue with degraded cuticle, charcoal, and wood fragments. Identifiable sporomorphs are modern Lycopodium spores added to calibrate abundances during palynological preparation.
As planned, the $\mathrm{CPCP}$ cores provide a venue for answering the major questions posed at the start of the project. Although work on these cores is still in its early stages, we can report some results and work in progress that address the questions set out during the project's origin as follows.

1. Is the Newark-Hartford Astrochronostratigraphiccalibrated magnetic Polarity Time-Scale (APTS) for the Late Triassic consistent with independent radioisotopic dates and magnetic polarity stratigraphy from the Chinle Formation? Thus far, we have been able to recover magnetostratigraphic polarity sequences from the full middle Sonsela through the entire Petrified Forest members of the Late Triassic-age Chinle Formation (40-240 msd) (Kent et al., 2018). Young euhedral detrital zircons apparently largely representative of the depositional age were identified in 29 out of 41 levels in core 1A surveyed using the LA-ICP-MS US NSF Facility at the University of Arizona, with about 100 to $>300$ crystals being dated in most samples. Of these, the youngest populations of the same zircons of 10 samples were selected thus far for CA-ID-TIMS dating 

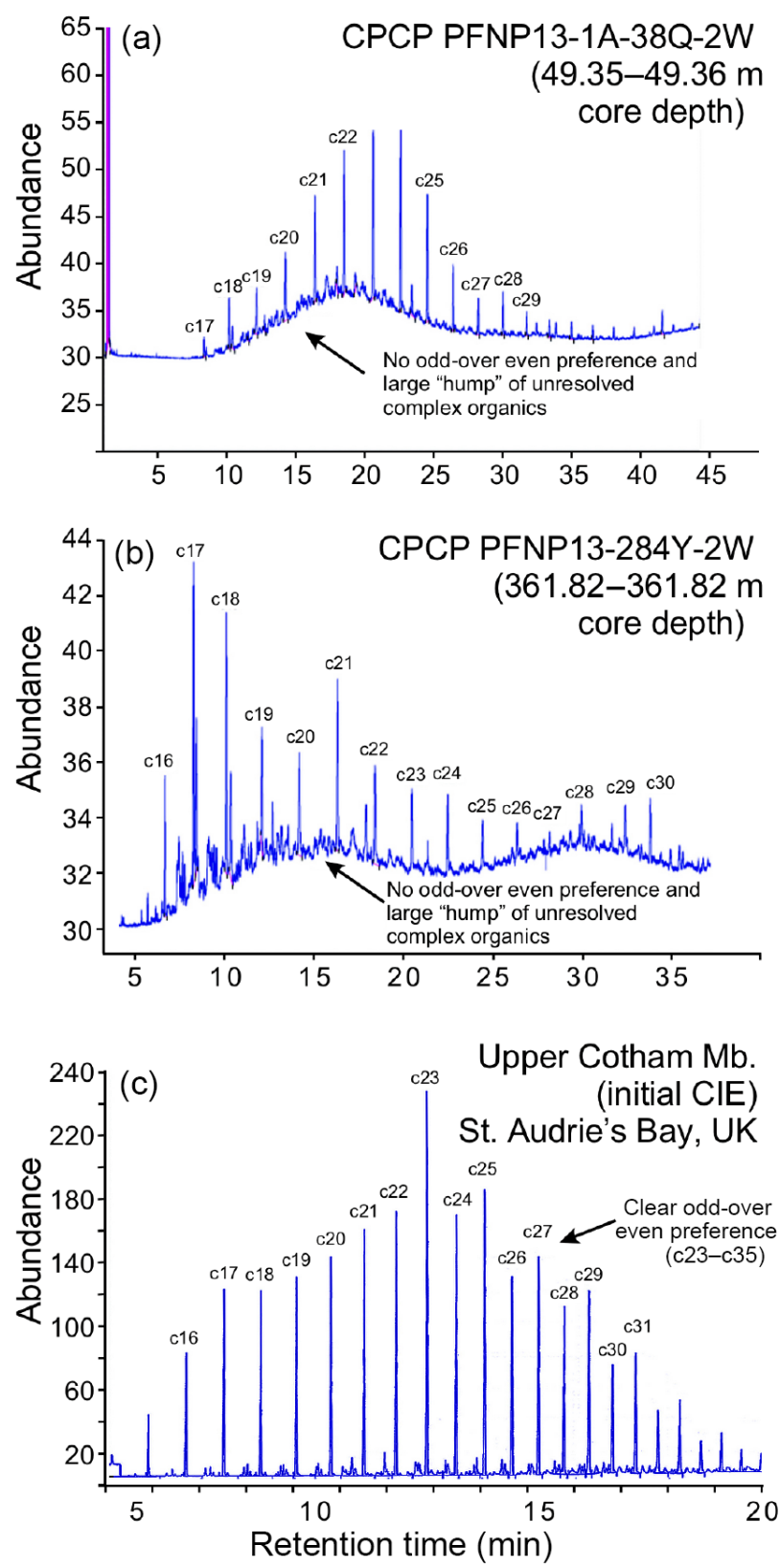

Figure 12. GC chromatogram traces for $n$-alkanes of the saturate fractions of the extracts from PNFP core samples. (a) Trace of CPCP PFNP13-1A-38Q-2W 47-48 cm in the Petrified Forest Member (=49.35-49.36 $\mathrm{m}$ core depth) from detector 1 , showing no odd-over-even preference of $n$-alkanes and a large hump of unresolved organic compounds, possibly due to organic degradation during pedogenesis or because the samples were too thermally mature. (b) Trace of CPCP PFNP13-1A-38Q-2A-284Y-1W 65-70 cm in the Blue Mesa Member (=361.82-361.82 m core depth) from detector 1, showing low abundance of organics, and mostly short chain $n$-alkanes characteristic of migrated, mature hydrocarbons. (c) Trace of the latest Rhaetian age upper Cotham Member, St. Audrie's Bay, Somerset, UK, with the $\delta^{13} \mathrm{C}$ initial excursion of Hesselbo et al. (2002) from Whiteside et al. (2010). at the Berkeley Geochronology Center yielding maximum depositional ages in stratigraphic order, within error four of which are published (Figs. 13 and 16). For the Chinle Formation these ages are consistent with published CA-ID-TIMS ages from outcrops in PFNP (Ramezani et al., 2011, 2014; Atchley et al., 2013). Of the new CA-ID-TIMS ages, four are registered to the Chinle magnetic polarity sequence from core 1A. The zircon-calibrated Petrified Forest and upper Sonsela member magnetostratigraphy fully validates the Newark-Hartford APTS, and answers the first major question addressed by the CPCP (Fig. 13) (Kent et al., 2018). It is important to note that correlation of the Newark-Hartford APTS with marine Tethyan strata resulted in a major revision to the duration of the divisions of Late Triassic, with the duration of the Norian Age increasing from 11-14 Myr (Gradstein et al., 1994; Ogg, 2004, 2012; Lucas, 2018) to $21 \mathrm{Myr}$ (Kent et al., 2017a), making it the longest age (stage) of the Phanerozoic. It also had the consequence of showing that the lower half of the Chinle Formation (of Adamanian Age) that was formerly regarded as Carnian (e.g., Lucas et al., 1993, 1998, 2010) is in fact Norian in age (Olsen et al., 2011). Based on these results we can show that a globally exportable timescale can be developed from cores of these types of continental strata. In addition, paleomagnetic and magnetic anisotropy data have been developed for all of the Moenkopi Formation in PFNP13-1A (Buhedma et al., 2016; Buhedma, 2017; McIntosh et al., 2017) (Figs. 14 and 15), and this CA-ID-TIMS zircon calibration of this sequence will provide an independent assessment of how faunal assemblages from this formation fit into the global recovery from the Permo-Triassic mass extinction. We anticipate working out the rest of the magnetostratigraphy in cores PFNP13-1A and in -2A and -2B, during 2018.

2. Were marine (Onoeue et al., 2016) and continental biotic turnover events in the Triassic synchronous? Specifically, was the apparent largest magnitude faunal turnover event on land during the Late Triassic (MidNorian, Adamanian-Revueltian boundary; Parker and Martz, 2011) synchronous with the giant Manicouagan bolide impact (Ramezani et al., 2013; Olsen et al., 2011), independent of it, or an artefact of a condensed section or hiatus, and does it correlate with the marine turnover? No certain representation of the "persistent red silcrete" that acts as a local stratigraphic marker of the Adamanian-Revueltian boundary in the southern part of the park was identified in the core 1A. This is not surprising because the "persistent red silcrete" occurs only in a very limited area in the northern area of the park and its possible equivalent, Billingsley's (1985) "brown sandstone" (Parker and Martz, 2011) has not 


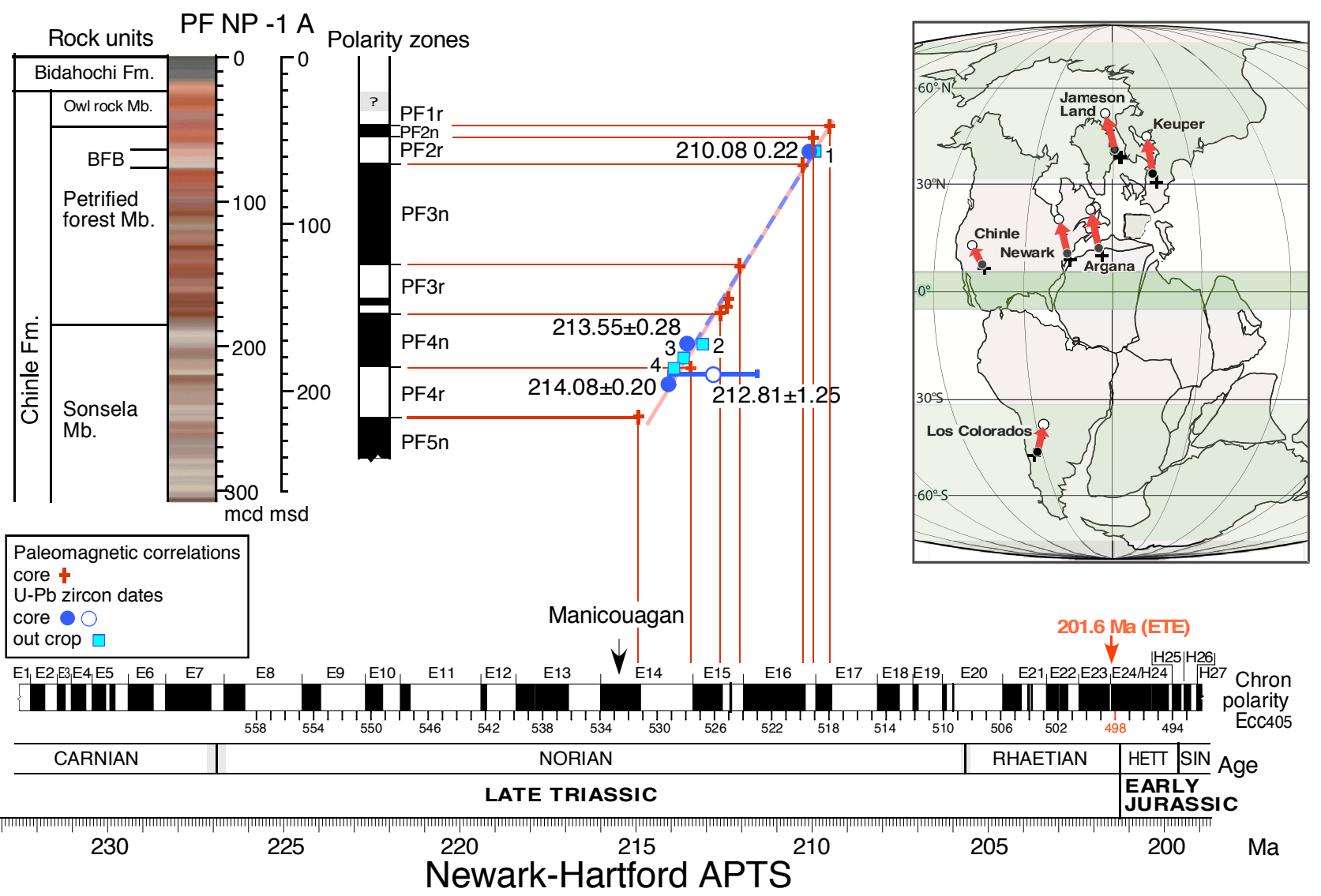

Figure 13. Depth versus age plot for core CPCP PFNP13-1A based on correlation of magnetostratigraphy with the Newark-Hartford APTS (from Kent et al., 2018). Stratigraphic units, graduated depths, and color log of CPCP PFNP13-1A. Red crosses are magnetozone boundaries in CPCP PFNP13-1A; correlated with the NH-APTS solid red line is a linear regression for base magnetozone PF1r to base magnetozone PF4r to their correlative chronological ages. Blue circles are U-Pb CA-ID-TIMS detrital zircon dates from CPCP PFNP13-1A; light blue squares are published U-Pb CA-TIMS detrital zircon dates from outcrop (from Ramezani et al., 2011; Atchley et al., 2013): 1, 209.93 $\pm 0.07 \mathrm{Ma}$; 2, 213.12 $\pm 0.07 \mathrm{Ma}$; 3, $213.63 \pm 0.13 \mathrm{Ma} ; 4,213.87 \pm 0.08 \mathrm{Ma}$. Linear regression on U-Pb ID-CA-TIMS dates (blue dashed line) based on sample data from core CPCP PFNP13-1A (excluding sample 177Q1); and light red line is regression of polarity boundaries in CPCP PFNP13-1A and Newark-Hartford APTS. U-Pb zircon date for Manicouagan crater impact melt rocks (Ramizani et al., 2005), which are characterized by normal polarity (Larochelle and Currie, 1967), is shown for reference. Inset shows a paleocontinental reconstruction of Pangea (from Kent et al., 2018) positioned according to a 220 Ma mean composite paleopole (Kent et al., 2014) with some key continental localities indicated by filled circles connected by arrows to their relative positions at 200 Ma by open circles.

yet been positively identified in the core either. There is also no reason to suspect these markers are related to the cause of the Adamanian-Revueltian boundary or the Manicouagan impact. Hence, additional fieldwork is needed to recover an unambiguous polarity stratigraphy to register the biotic transition with the core magnetic stratigraphy. We do know that at least broadly speaking the marine turnover is close in time to the AdamanianRevueltian boundary. However, additional work will be needed, presumably by others, to place the marine biotic changes in a magnetostratigraphic context that is thus far lacking except for a very few sections (e.g., Muttoni et al., 2004, 2014).
3. Is the apparent pattern of latitudinal biotic provinciality seen in the Late Triassic supported by high-resolution, independent (i.e., non-biostratigraphic) correlations and does that change with climate-related environmental proxies? The match of the magnetic polarity stratigraphy and zircon $\mathrm{U}-\mathrm{Pb}$ dates from core $1 \mathrm{~A}$ to the NewarkHartford APTS (Kent et al., 2018) and a rather obvious correlation with magnetic polarity stratigraphy records through North and South America shows that the apparent pattern of latitudinal biotic provinciality seen in the Late Triassic is supported by high-resolution independent (i.e., non-biostratigraphic) correlations (Fig. 16). This means that the strong biotic provinciality of Triassic Pangea, and the 30 million-year delay in the rise of dinosaurian ecological dominance in the tropics (White- 

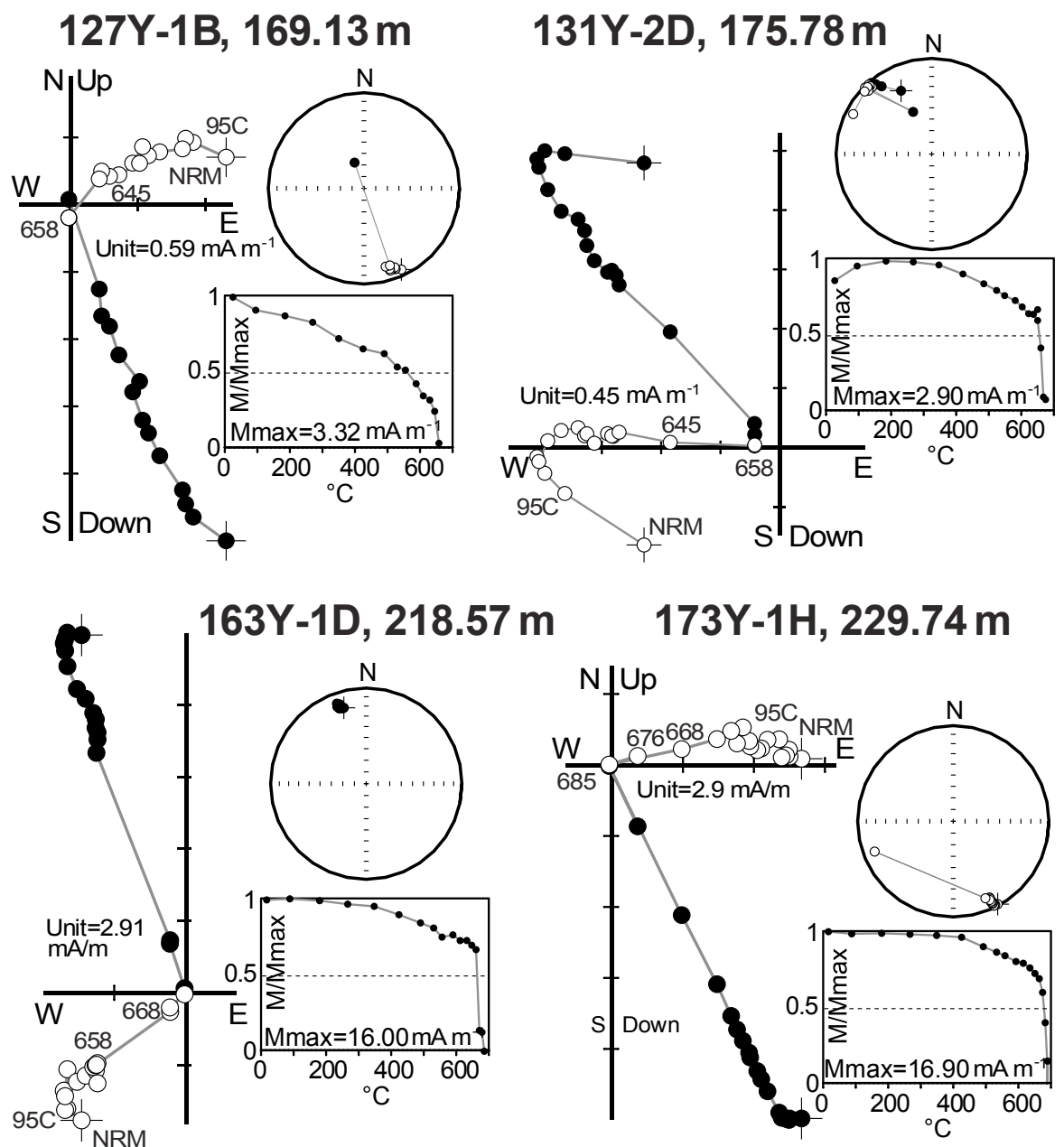

\section{Y-1H, $229.74 \mathrm{~m}$}

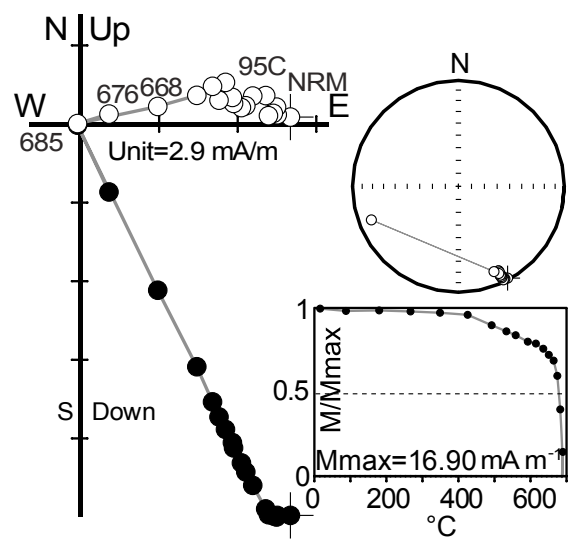

Figure 14. Examples of orthogonal progressive demagnetization diagrams for the Moenkopi Formation showing the end point of the magnetization vector plotted onto the horizontal (filled symbols) and vertical (open symbols) planes (NS-EW, EW-Up/Dn) for individual specimens from core segments of Moenkopi Formation rocks intersected in CPCP Phase 1 Core 2B that have been subjected to progressive thermal demagnetization. Demagnetization steps, in temperatures $\left({ }^{\circ} \mathrm{C}\right)$ are given alongside selected vertical projection data points. NRM is the natural remanent magnetization. Also shown are normalized intensity decay plots showing response to progressive thermal treatment (abscissa is temperature, ${ }^{\circ} \mathrm{C}$ ) and equal area stereographic projections of the magnetization vector measured at each step. Note that the coordinate axes for each and every diagram are identical in orientation and the diagrams are in geographic coordinates, assuming that each core segment is properly oriented.

side et al., 2011, 2015) indicated by previous correlations using the Newark-Hartford APTS, is not an artefact of biostratigraphic miscorrelation as asserted by some (e.g., Lucas, 2018), but a real feature of that world which can now be quantified both in time and space (Kent et al., 2018).

4. Is the orbitally paced (Milankovitch) cyclical climate change recorded in the Newark basin lacustrine deposits reflected in the largely fluvial Chinle and Moenkopi formations? Based on work still underway, a perhaps surprising preliminary result from the Petrified Forest and upper Sonsela members is that the $405 \mathrm{kyr}$ cycle is in fact reflected in the Chinle Formation, as seen in the redox-sensitive magnetic susceptibility logs (Olsen et al., 2017) (Fig. 5). A lower-frequency cycle around $1.8 \mathrm{Myr}$ is present as well and is also seen in the Newark record (Olsen et al., 1999). Higher-frequency orbital cycles have yet to be identified with certainty, although there is a hint of some $\sim 100$ ky cyclicity in the magnetic susceptibility logs. Additional work with other environmental proxies, including the CT scans of paleosol fabrics (Fig. 8), and analysis of the rest of the section and cores should provide a deeper knowledge of how the cycles are expressed in the fluvial environments.

5. Do $p \mathrm{CO}_{2}$ proxies in the western US track those from the eastern US, and how do they relate to the records 


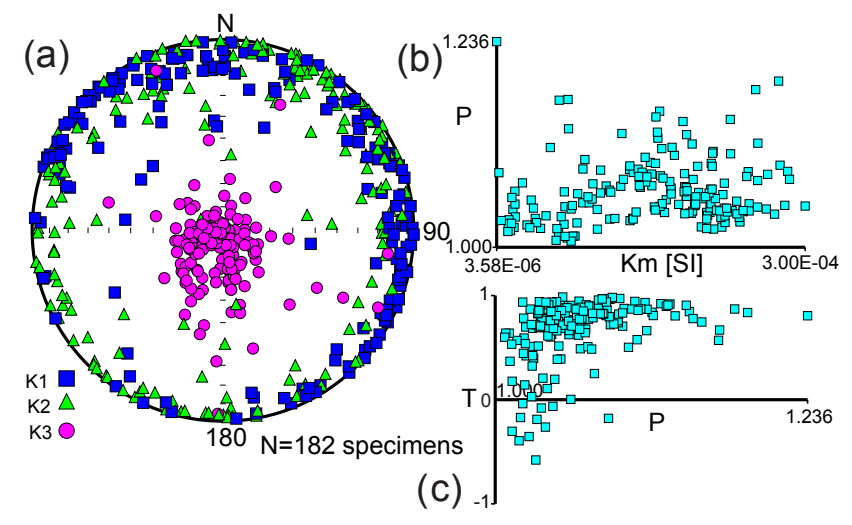

Figure 15. Preliminary anisotropy of magnetic susceptibility (AMS) data from Moenkopi Formation rocks intersected in CPCP Phase 1 Core 2B. (a) The stereographic projection shows the principal susceptibility axes $\left(K_{1}, K_{2}, K_{3}=K_{\max }, K_{\text {int }}, K_{\min }\right)$ for each specimen measured (lower hemisphere projections). (b) The anisotropy parameter $P$, where $P=K_{\max } / K_{\min }$, is plotted vs. bulk susceptibility for each specimen measured. (c) The anisotropy parameter $T$, where $T$, the shape parameter $\left(=\left(\left[2 \ln K_{\mathrm{int}}-\ln K_{\max }-\right.\right.\right.$ $\left.\left.\ln K_{\min }\right] /\left[\ln K_{\max }-\ln K_{\min }\right]\right)$ is plotted vs. $P . T$ values close to 1.0 are associated with strong oblate fabrics. In (a) the data from most Moenkopi rocks show a fabric that is typical of very fine-grained detrital sedimentary rocks, with the minimum susceptibility axis essentially vertical and overall well grouped. The principal susceptibility axes are plotted assuming that all sampled core segments are properly oriented; as discussed in the text this assumption is likely not always valid and thus improper core orientation may be a source of some of the observed dispersion in the data. An additional source of dispersion is that some Moenkopi facies may have preserved a well-defined sedimentary imbrication fabric, where the minimum susceptibility axis is canted from the vertical.

of environmental change seen in the cores, and other areas? Preliminary results from parts of core $1 \mathrm{~A}$ show that the carbonate paleosol $p \mathrm{CO}_{2}$ proxy does yield comprehensible results consistent with those from the eastern US (Schaller et al., 2015; Whiteside et al., 2015). At least one major fluctuation falls in the age range of the CPCP-PFNP13-1A core with a $p \mathrm{CO}^{2}$ local minimum at about 211-212 Ma (Knobbe and Schaller, 2018), associated with a Norian temperature low (Trotter et al., 2016). There are also encouraging results that atmospheric $\mathrm{O}_{2}$ concentrations are obtainable from the same soil carbonates from the CPCP cores and eastern North America (Schaller et al., 2017). Other fluctuations in $p \mathrm{CO}_{2}$, such as the Rhaetian drop and the Hettangian rise associated with the emplacement of the Central Atlantic Magmatic Province (CAMP) as well as the supposed Carnian "Pluvial" (Ruffell et al., 2016), do not fall within the age range of these cores.

\section{Outreach and broader impacts}

Petrified Forest National Park is a major tourist destination with some 600000 visitors per year from around the world who are predisposed to be receptive to a geologic narrative. To highlight the CPCP and its potential for public education and outreach, the National Park Service posted a link devoted to the project (https://www.nps.gov/pefo/learn/nature/coring.htm, last access: September 2018), and produced a flyer that was distributed while we were on-site. During drilling we hosted several tours for local residents and tourists. There was significant international to local publicity associated with the project, including Nature (http://www.nature.com/news/geologists-take-drill-to-

triassic-park-1.13866, last access: September 2018), PLos Blogs (http://blogs.plos.org/paleo/2013/11/21/thecolorado-plateau-coring-project-getting-dates-in-thetriassic/, last access: September 2018), Arizona Geology (http://arizonageology.blogspot.com/2013/11/scientificcore-drilling-at-petrified.html, last access: September 2018), Discover Magazine (http://discovermagazine.com/2015/may/18-sands-oftime, last access: September 2018), National Geographic (http://phenomena.nationalgeographic.com/2013/11/19/ getting-to-the-core-of-the-triassic/, last access: September 2018), WNYC (https://www.wnyc.org/story/shutdownstymies-scientific-research/, last access: September 2018), and the Arizona Daily Sun (http://azdailysun.com/news/local/petrified-forest-afossil-every-inches/article_ee70579c-4906-11e3-9324001a4bcf887a.html, last access: September 2018). A time-lapse video by Max Schnurrenberger of rig set up and coring set to music is posted as well (https://www.youtube.com/watch?v=0cbWuKnmVKk and linked to the CPCP site http://www.ldeo.columbia.edu/\$ \$ polsen/cpcp/PFCP_13_ main.html, last access: September 2018) and the LacCore group developed and maintains a Facebook page for the project (https://www.facebook.com/Colorado-PlateauCoring-Project-1436554049899932/, last access: September 2018), with news updates throughout drilling, and coordinated workforce development training in drilling and core workflows for five people, which developed over 300 likes and nearly as many followers during the coring period. The ultimate goal of Petrified Forest National Park is to provide a million-year (at least) resolution time line of the 20 million-year history of the area during the Triassic and then tying this through to the modern era. The data from the cores will be a big part of generating this story as exhibits develop. A permanent website for the project was developed and is maintained by PEO (http://www.ldeo.columbia.edu/ $\sim$ polsen/cpcp/CPCP_home_page_general.html, last access: September 2018). The latter has seen over 12000 visitors. 


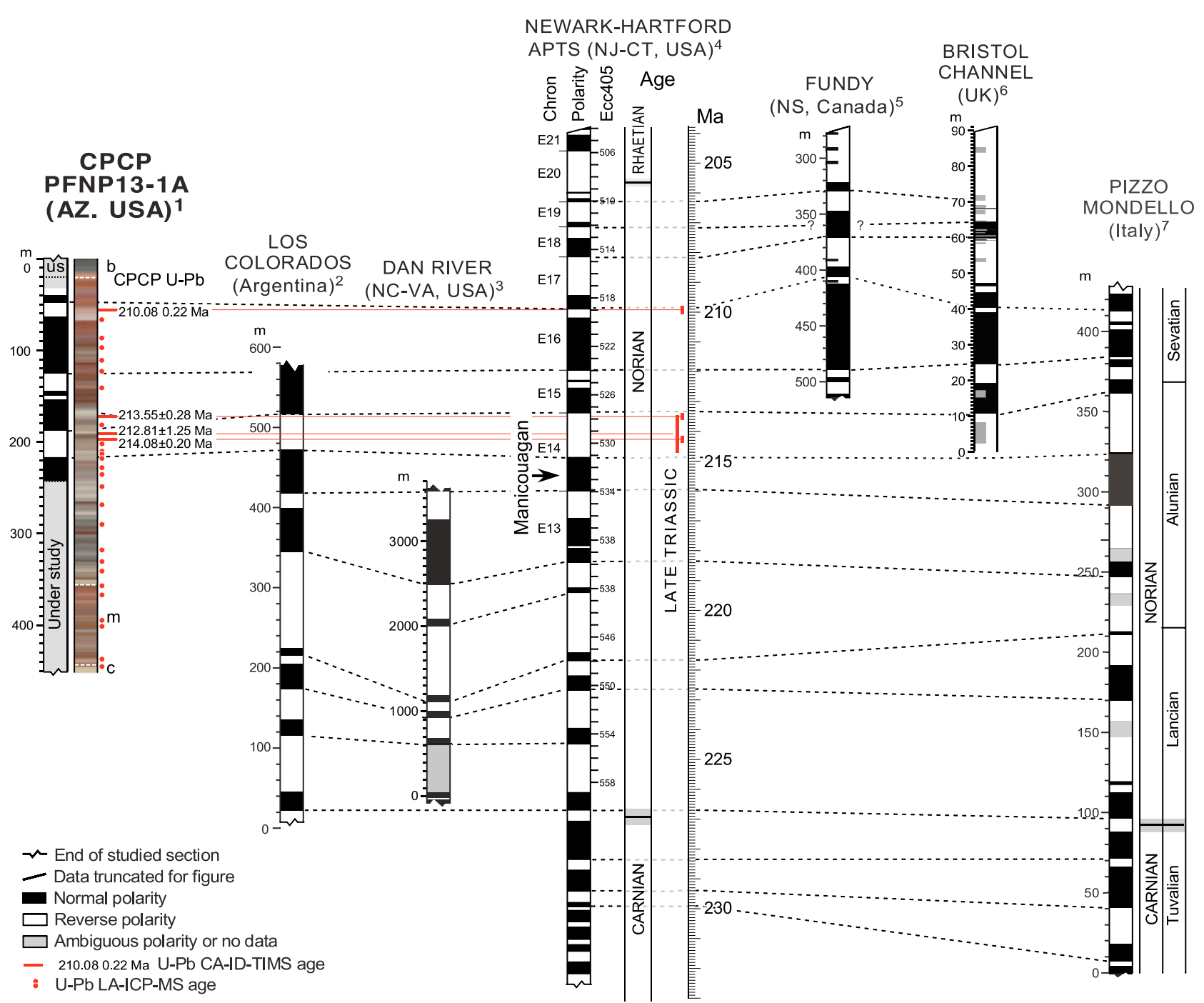

Figure 16. Paleomagnetic polarity stratigraphy of the upper part of the Chinle Formation in CPCP PFNP-13-1A correlated with the NewarkHartford APTS and sections in Argentina, eastern North America (Dan River and Fundy basins), the UK, and Italy. Dotted white lines in the CPCP section are formation boundaries. Note that no correlation is implied for the Chinle Formation below $245 \mathrm{~m}$ stratigraphic depth. Sections are shown in stratigraphic (thickness) coordinates, except the APTS, which is in time, pinned to zircon U-Pb dates from the Central Atlantic Magmatic Province (CAMP) (Blackburn et al., 2013) and tuned to the $405 \mathrm{kyr}$ orbital cycle. CPCP zircon U-Pb ages are correlated (horizontal red lines) with the Newark-Hartford APTS by paleomagnetic polarity stratigraphy and a linear age-depth model (Kent et al., 2018) (with the analytical error shown by the vertical red bars). Each paleomagnetic polarity stratigraphy is independently correlated in this diagram with the Newark-Hartford APTS via the first and last polarity boundaries according to the original author (not shown for the sections truncated here). Additional abbreviations are Ecc405, the Jupiter-Venus eccentricity cycle of a 405 kyr period; us, unsampled; b, Neogene Bidahochi Formation; m, Early to nominally Middle Triassic Moenkopi Formation; and c, Early Permian Coconino Sandstone. Sources are ${ }^{1}$ Kent et al. (2018); ${ }^{2}$ Kent et al. (2014); ${ }^{3}$ Kent and Olsen (1999) and Olsen et al. (2015); ${ }^{4}$ Kent et al. (2017); ${ }^{5}$ Kent and Olsen (2000); ${ }^{6}$ Hounslow et al. (2004) and Briden and Daniels (1999); and ${ }^{7}$ Muttoni et al. (2004) and Kent et al. (2017).

The CPCP has included and will continue to include significant career training and mentoring. Thus far, this has included post-doctoral fellow Charlotte Miller (University of Oslo); PhD graduate fellows Cornelia Rasmussen (University of Utah), Sean Kinney (Columbia University), and Viktória Baranyi (University of Oslo); MSc graduate students Dominique Geisler (University of Arizona) and Hes- ham Buhedma (University of Texas at Dallas); and undergraduate honors student Julia McIntosh (University of Texas at Dallas). 


\section{Continuing science and plans}

The Petrified Forest National Park part of the CPCP is in the post-drilling science phase. Preliminary results were presented at the AGU national meetings in 2013, 2014, 2016 (P. E. Olsen et al., 2013, 2014; Geissman et al., 2014; Buhedma et al., 2016), the Geological Society of America national meeting (Irmis et al., 2014), the Society of Vertebrate Paleontology Meeting in Berlin (P. Olsen et al., 2014a), the International Paleontological Congress in Mendoza Argentina (P. Olsen et al., 2014b), the International Geological Congress in Cape Town, SA (P. Olsen et al., 2016; P. E. Olsen et al., 2016; Geissman et al., 2016), and an AGU national meeting special session in 2017 entitled, "Chronostratigraphic Advances Integrating Paleomagnetism, Tephra, Climate Correlation, and Other Stratigraphic and Proxy Methods to Solve Earth System Processes and Events" (Irmis et al., 2017; Kent et al., 2017b; McIntosh et al., 2017; Olsen et al., 2017; Rasmussen et al., 2017; Schaller et al., 2017). Peer-reviewed publications have begun appearing this year (e.g., Kent et al., 2018). It is not an overstatement to conclude that the results from the CPCP project have transformed one of the poorest calibrated intervals of the Phanerozoic to one of the best. Our success at providing an independent and globally exportable zircon U-Pb-calibrated, paleomagnetic polarity stratigraphy, and atmospheric gas constraints from these kinds of continental sequences and their applicability to regional and global problems, has already resulted in a fundamental advance (Kent et al., 2018) and will spur future efforts in other parts of the geologic column. Plans for CPCP Phase 2 are underway with an international workshop that will coordinate efforts at building on Phase I of the CPCP, extending the core record though the rest of the Late Triassic, the Triassic-Jurassic transition, and nearly the complete Early Jurassic. The CPCP Phase 2 project will be coordinated with the ongoing JET project (https://www. facebook.com/JETMochras/, last access: September 2018) in the cyclical Early Jurassic marine epicontinental Jurassic of the UK. Ideally it will be paired with coring a high-latitude site, together resulting in an unprecedented synoptic view of Triassic to Jurassic $p \mathrm{CO}_{2}$, climate evolution and orbital pacing, and biotic transitions, including two mass extinctions and the rise to ecological dominance of the dinosaurs. A ICDP-funded workshop on these possible coring projects is planned for May 2019.

Team list. G. Bachman, V. Baranyi, R. Blakey, K. Brady Shannon, H. Buhedma, M. Colbert, D. Edey, G. Gehrels, J. Geissman, D. Giesler, Z. Haque, R. Irmis, D. Kent, S. Kinney, W. Kürschner, C. Lepre, J. MacIntosh, J. Maisano, C. Miller, R. Molina-Garza, R. Mundil, A. Noren, R. O'Grady, P. Olsen, W. Parker, C. Rasmussen, M. Schaller, D. Schnurrenberger, J. Sha, J. Whiteside, N. Zakharova. The CPCP teams include all of the authors plus R. Blakey, Z. Haque, and J. MacIntosh.
Data availability. The underlying data for this paper, not already presented in previous papers, are freely available from https://osf.io/5vd8u/ at this persistent DOI: https://doi.org/10.17605/OSF.IO/5VD8U (Stone et al., 2016). The archive split of the CPCP cores are stored at the LacCore, National Lacustrine Core Repository (http://lrc.geo.umn.edu/laccore/repository.html, last access: September 2018) and the working split is at the Rutgers University Core Repository where available (https://eps.rutgers.edu/centers-institutes/rutgers-core-repository, last access: September 2018).

Author contributions. PEO, JWG, DVK, GEG, RM, RBI, WGP, WMK, RMG, GHB, RMG, JHW, GHB, RCB, and JS designed research. PEO, JWG, DVK, GEG, RM, RBI, CL, CR, DG, WGP, NZ, WMK, CM, VB, HB, MFS, JHW, DS, AN, KBS, RO'G, MWC, JM, DE, STK, RMG, GHB, RCB, and JS designed research. PEO, JWG, DVK, GEG, RM, RBI, CL, CR, DG, WGP, NZ, WMK, CM, VB, HB, MFS, DS, AN, KBS, RO'G, MWC, JM, DE, STK, RMG, JMI, ZH, performed research. PEO, JWG, DVK, GEG, RM, RBI, CL, CR, DG, NZ, WMK, CM, VB, HB, MFS, JHW, and STK analyzed data. PEO, JWG, DVK, GEG, RM, RBI, WGP, WMK, CM, JHW, and STK wrote the paper.

Competing interests. The authors declare that they have no conflict of interest.

Disclaimer. Any opinions, findings, or conclusions of this study represent the views of the authors and not those of the U.S. Federal Government.

Acknowledgements. We thank the National Park Service and particularly superintendent Brad Traver for permission to core in the park and for logistical support during site selection and drilling. Primary funding for this project is from NSF collaborative grants EAR 0958976 (Olsen, Geissman), 0958859 (Kent), 0959107 (Gehrels), 0958723 (Mundil), 958915 (Irmis) and ICDP (International Scientific Continental Drilling Program grant 05-2010: Geissman, Olsen, Sha, Molina-Garza, Kürschner, Bachmann), and we thank the late Richard Lane of NSF and Ulrich Harms for their persistent guidance through the funding process. We acknowledge support for the LaserChron Center from EAR 1649254, for the LacCore Facility from EAR 1462297 and EAR 0949962, and for CSDCO Facility from EAR 1338322, and for the University of Texas High Resolution X-ray CT Facility from EAR 1258878. The palynological and organic geochemisty research was funded by the FRINATEK grant no. 213985 (Kürschner), FRINATEK overseas travel grant 244926/BG (Kürschner/Miller) and funding from the Faculty of Mathematics and Natural Sciences at the University of Oslo (Norway) (Kürschner/Baranyi) and the Lamont-Climate Center. We are very grateful to the on-site core-handling volunteers Justin Clifton, Bob Graves, Ed Lamb, Max Schnurrenberger, and Brian Switek for their round-the-clock efforts! We also thank Nancy Riggs (Northern Arizona University) for helpful discussion. All thermal demagnetization data and all anisotropy of magnetic 
susceptibility (AMS) data collected by Ziaul Haque, PhD candidate, University of Texas at Dallas. Jingeng Sha acknowledges support from the National Natural Science Foundation of China (41730317), Special Basic Program of Ministry of Science and Technology of China (2015FY310100), and Bureau of Geological Survey of China and National Committee of Stratigraphy of China (DD20160120-04). This is a contribution to IGCP-632, LDEO Contribution 8231, and Petrified Forest Paleontological Contribution 55.

Edited by: Jan Behrmann

Reviewed by: Celina Suarez and two anonymous referees

\section{References}

Allen, V. T.: Triassic bentonite of the Painted Desert, Am. J. Sci., 112, 283-288, 1930.

Ash, S. R.: Late Triassic plants from the Chinle Formation in northeastern Arizona, Palaeontology, 15, 598-618, 1972.

Ash, S. R.: A catalog of Upper Triassic plant megafossils of the western United States through 1988, in: Dawn of the Age of Dinosaurs in the American Southwest, Albuquerque, New Mexico, edited by: Hunt, A. P. and Lucas, S. G., Museum of Natural History, 189-222, 1989.

Ash, S. R.: Synopsis of the Upper Triassic flora of Petrified Forest National Park and vicinity, Mesa Southwest Mus. Bull., 9, 5362, 2005.

Atchley, S. C., Nordt, L. C., Dworkin, S. I., Ramezani, J., Parker, W. G., Ash, S. R., and Bowring, S. A.: A linkage among Pangean tectonism, cyclic alluviation, climate change, and biologic turnover in the Late Triassic: The Record From The Chinle Formation, Southwestern United States, J. Sed. Res. 83, 11471161, 2013.

Baag, C. G. and Helsley, C. E.: Remanent magnetization of a $50 \mathrm{~m}$ core from the Moenkopi Formation, western Colorado, Geophys, J. Internat., 37, 245-262, 1974.

Banham, S. G. and Mountney, N. P.: Climatic versus halokinetic control on sedimentation in a dryland fluvial succession, Sedimentology, 61, 570-608, 2014.

Baranyi, V., Reichgelt, T., Olsen, P. E., Parker, W. G., and Kürschner, W. M.: Norian vegetation history and related environmental changes: new data from the Chinle Formation, Petrified Forest National Park (Arizona, SW USA), Geol. Soc. Am. Bull., 130, 775-795, https://doi.org/10.1130/B31673.1, 2017.

Barth, A. P. and Wooden, J. L.: Timing of magmatism following initial convergence at a passive margin, southwestern US Cordillera, and ages of lower crustal magma sources, J. Geol., 114, 231-245, 2006.

Billingsley, G. H.: General stratigraphy of the Petrified Forest National Park, Arizona, Mus. Northern Ariz. Bull., 54, 3-8, 1985.

Blackburn, T. J., Olsen, P. E., Bowring, S. A. , McLean, N. M., Kent, D. V., Puffer, J., McHone, G., Rasbury, E. T., and Et-Touhami, M.: Zircon U-Pb geochronology links the end-Triassic extinction with the Central Atlantic Magmatic Province, Science, 340, 941945, 2013

Bown, P. R., Lees, J. A., and Young, J. R.: Calcareous nannoplankton evolution and diversity through time, in: Coccolithophores: from molecular processes to global impact, edited by: Thierstein,
H. R. and Young, J. R., Springer-Verlag Berlin, Heidelberg, 481508, 2004.

Briden, J. C. and Daniels, B. A.: Palaeomagnetic correlation of the Upper Triassic of Somerset, England, with continental Europe and eastern North America, J. Geol. Soc., 15, 317-326, 1999.

Bryan, P. and Gordon, R. G.: Rotation of the Colorado Plateau: An analysis of paleomagnetic data, Tectonics, 5, 661-667, 1986.

Buhedma, H. M. A.: Magnetostratigraphy of the Chinle and Moenkopi Strata Cored at Colorado Plateau Coring Project Site 1A, Northern Petrified Forest National Park, MSc Thesis, University of Texas, Dallas, 41 p., 2017.

Buhedma, H. M. A., Geissman, J. W., McIntosh, J., Olsen, P. E., and Kent, D. V.: Preliminary magnetic polarity stratigraphy and rock magnetic data from the continuous cored record of Triassic continental environmental change, the Colorado Plateau Coring Project. AGU, 2016 Fall Meeting, paper GP31B-1298, available at: https://agu.confex.com/agu/fm16/meetingapp.cgi/Paper/ 144302 (last access: September 2018), 2016.

Burchfiel, B. C. and Davis, G. A.: Structural framework and structural evolution of the southern part of the Cordilleran orogen, western United States, Am. J. Sci., 272, 97-118, 1972.

Chemenda, A., Matte, P., and Sokolov, V.: A model of Palaeozoic obduction and exhumation of high-pressure/low-temperature rocks in the southern Urals, Tectonophysics, 276, 217-227, 1997.

Clyde, W. C., Gingerich, P. D., Wing, S. L., Röhl, U., Westerhold, T., Bowen, G., Johnson, K., Baczynski, A. A., Diefendorf, A., McInerney, F., Schnurrenberger, D., Noren, A., Brady, K., and the BBCP Science Team: Bighorn Basin Coring Project (BBCP): a continental perspective on early Paleogene hyperthermals, Sci. Dril., 16, 21-31, https://doi.org/10.5194/sd-16-21-2013, 2013.

Cohen, A., Campisano, C., Arrowsmith, R., Asrat, A., Behrensmeyer, A. K., Deino, A., Feibel, C., Hill, A., Johnson, R., Kingston, J., Lamb, H., Lowenstein, T., Noren, A., Olago, D., Owen, R. B., Potts, R., Reed, K., Renaut, R., Schäbitz, F., Tiercelin, J.-J., Trauth, M. H., Wynn, J., Ivory, S., Brady, K., O’Grady, R., Rodysill, J., Githiri, J., Russell, J., Foerster, V., Dommain, R., Rucina, S., Deocampo, D., Russell, J., Billingsley, A., Beck, C., Dorenbeck, G., Dullo, L., Feary, D., Garello, D., Gromig, R., Johnson, T., Junginger, A., Karanja, M., Kimburi, E., Mbuthia, A., McCartney, T., McNulty, E., Muiruri, V., Nambiro, E., Negash, E. W., Njagi, D., Wilson, J. N., Rabideaux, N., Raub, T., Sier, M. J., Smith, P., Urban, J., Warren, M., Yadeta, M., Yost, C., and Zinaye, B.: The Hominin Sites and Paleolakes Drilling Project: inferring the environmental context of human evolution from eastern African rift lake deposits, Sci. Dril., 21, 1-16, https://doi.org/10.5194/sd-21-1-2016, 2016.

Daugherty, L. H.: Upper Triassic flora of Arizona, Carnegie Institute of Washington Publication, 526, 1-108, 1941.

DeCelles, P. G. and Giles, K. A.: Foreland basin systems, Basin Research, 8, 105-123, 1996.

Demko, T. M.: Taphonomy of fossil plants in Petrified Forest National Park, Arizona, Mesa Southwest Mus. Bull., 3, 37-52, 1995.

Demko, T. M., Dubiel, R. F., and Parrish, J. T.: Plant taphonomy in incised valleys: implications for interpreting paleoclimate from fossil plants, Geology, 26, 1119-1122, 1998.

Dickinson, W. R.: Tectonosedimentary Relations of Pennsylvanian to Jurassic strata on the Colorado Plateau, Geol. Soc. Am. Special Paper 533, 184 p., https://doi.org/10.1130/2018.2533, 2018. 
Dickinson, W. R. and Gehrels, G. E.: U-Pb ages of detrital zircons in relation to paleogeography: Triassic paleodrainage networks and sediment dispersal across southwest Laurentia, J. Sed. Res., 78, 745-764, 2008a.

Dickinson, W. R. and Gehrels, G. E.: Sediment delivery to the Cordilleran foreland basin: Insights from $\mathrm{U}-\mathrm{Pb}$ ages of detrital zircons in Upper Jurassic and Cretaceous strata of the Colorado Plateau, Am. J. Sci, 308, 1041-1082, 2008b.

Dickinson, W. R. and Gehrels, G. E.: Use of U-Pb ages of detrital zircons to infer maximum depositional ages of strata: a test against a Colorado Plateau Mesozoic database, Earth Planet. Sc. Lett., 288, 115-125, 2009.

Eckmeier, E. and Wiesenberg, G. L.: Short-chain n-alkanes (C 1620) in ancient soil are useful molecular markers for prehistoric biomass burning, J. Archaeol. Sci., 36, 1590-1596, 2009.

Eriksson, P. G., Bose, P. K., Catuneanu, O., Sarkar, S., and Banerjee, S.: Precambrian clastic epeiric embayments: examples from South Africa and India, in: Dynamics of Epeiric Seas, edited by: Pratt, B. R. and Holmden, C., Geological Assoc. Canada, Special Papers 48, 119-136, 2008.

Fisher, M. J. and Dunay, R. E.: Palynology of the Petrified Forest member of the Chinle Formation (Upper Triassic), Arizona, U.S.A., Pollen Spores, 26, 241-284, 1984.

Flowers, R. M.: The enigmatic rise of the Colorado Plateau, Geology, 38, 671-672, 2010.

Foster, G. L., Royer, D. L., and Lunt, D. J.: Future climate forcing potentially without precedent in the last 420 million years, Nature Comm., 8, 14845, https://doi.org/10.1038/ncomms14845, 2017.

Gallet, Y., Krystyn, L., Besse, J., and Marcoux, J.: Improving the Upper Triassic numerical time scale from crosscorrelation between Tethyan marine sections and the continental Newark basin sequence, Earth Planet. Sc. Lett., 212, 255-261, https://doi.org/10.1016/S0012-821X(03)00290-5, 2003.

Gehrels, G. E., Dickinson, W. R., Darby, B. J., Harding, J. P., Manuszak, J. D., Riley, B. C. D., Spurlin, M. S., Finney, S. C., Girty, G. H., Harwood, D. S., Miller, M., M., Satterfield, J. I., Smith, M. T., Snyder, W. S., Wallin, E. T., and Wyld, S. J.: Tectonic implications of detrital zircon data from Paleozoic and Triassic strata in western Nevada and northern California, in: Paleozoic and Triassic Paleogeography and Tectonics of Western Nevada and Northern California, edited by: Soreghan, M. J. and Gehrels, G. E., Geol. Soc. Am. Spec. Pap. 347, 133-150, 2000.

Geissman, J. W., Olsen, P. E., and Kent, D. V.: Site selected for Colorado Plateau Coring: Colorado Plateau Coring Project: Colorado Plateau Coring Project Workshop, Phase 2: 100 Million Years of Climatic, Tectonic, and Biotic Evolution from Continental Coring, EOS, Trans. Am. Geophys. Union, 91, 1349-1368, 2010.

Geissman, J. G., Olsen, P. E., Kent, D. V., Irmis, R. B., Gehrels, G. E., Mundil, R., Parker, W., Bachmann, G. H., Kuerschner, W. M., Molina-Garza, R., and Sha, J.: The inception of the Colorado Plateau Coring Project: Filling the Triassic geochronologic gap and providing a continuous record of continental environmental change in western equatorial Pangea, AGU, 2014 Fall Meeting, Abstracts, Paper 11439, PP31C-1145, 2014.

Geissman, J. W., Buhedma, H., MacIntosh, J. A., Olsen, P. E., and Kent, D.: The Colorado Plateau (USA) Coring Project (CPCP): Preliminary magnetic polarity stratigraphy and rock magnetic data from the continuous cored record of Triassic continental environmental change, Internat. Geol. Cong., Abstracts 35; Paper number 4254, 35th international geological 65, Cape Town, South Africa, 27 August-4 September 2016, 2016.

Gottesfeld, A. S.: Palynology of the Chinle Formation, Suppl. Mus. Northern Ariz. Bull., 47, 13-18, 1972.

Gradstein, F. M., Agterberg, F. P., Ogg, J. G., Hardenbol, J., Van Veen, P., Thierry, J., and Huang, Z.: A Mesozoic time scale, J. Geophys. Res., 99, 24051-24074, 1994.

Gradstein, F. M., Ogg, J. G., Schmitz, M. D., and Ogg, G. M. (Eds.): The Geologic Time Scale 2012, Elsevier, Amsterdam (1144 pp.), 2012.

Hamilton, W.: Plate-tectonic mechanism of Laramide deformation, Contributions to Geology-University of Wyoming, Laramie, 19, 87-92, 1981.

Hartley, A. and Evenstar, L.: Fluvial architecture in actively deforming salt basins: Chinle Formation, Paradox Basin, Utah, Basin Research, 1-19, https://doi.org/10.1111/bre.12247, 2017.

Hazel, J. E.: Sedimentary response to intrabasinal salt tectonism in the Upper Triassic Chinle Formation, Paradox basin, Utah, U.S. Geol. Surv. Bull. 2000-F, F1-F34, 1994.

Heckert, A. B.: Late Triassic microvertebrates from the lower Chinle Group (Otischalkian-Adamanian: Carnian) southwestern U.S.A., NM Mus. Nat. Hist. Sci. Bull., 27, 170 pp., 2004.

Heckert, A. B. and Lucas, S. G.: Revised Upper Triassic stratigraphy of the Petrified Forest National Park, Arizona, USA. NM Mus. Nat. Hist. Sci. Bull., 21, 1-36, 2002.

Hesselbo, S. P., Robinson, S. A., Surlyk, F., and Piasecki, S.: Terrestrial and marine extinction at the Triassic-Jurassic boundary synchronized with major carbon-cycle perturbation: A link to initiation of massive volcanism?, Geology, 30, 251-254, 2002.

Heylmun, E. B.: Arizona's Holbrook salt basin holds oil, gas opportunities, Oil and Gas Journal, 95, 127-132, 1997.

Hildebrand, R. S.: Did westward subduction cause CretaceousTertiary orogeny in the North American Cordillera?, Geol. Soc. Am. Spec. Pap., 457, 1-71, 2009.

Hildebrand, R. S.: Mesozoic assembly of the North American cordillera, Geol. Soc. Am. Spec. Pap., 495, 169 pp., 2013.

Hilgen, F. J., Krijgsman, W., Langereis, C. G., and Lourens, L. J.: Breakthrough made in dating of the geological record, EOS, Trans. Am. Geophys. Union, 78, 285-289, 1997.

Hounslow, M. W., Posen, P. E., and Warrington, G.: Magnetostratigraphy and biostratigraphy of the Upper Triassic and lowermost Jurassic succession, St. Audrie's Bay, UK, Palaeogeo. Palaeoclim. Palaeoeco., 213, 331-358, 2004.

Howell, E. R. and Blakey, R. C.: Sedimentological constraints on the evolution of the Cordilleran arc: New insights from the Sonsela Member, Upper Triassic Chinle Formation, Petrified Forest National Park (Arizona, USA), Geol. Soc. Am. Bull., 125, 13491368, https://doi.org/10.1130/B30714.1, 2013.

Huber, P., Olsen, P. E., and LeTourneau, P. M.: Incipient Pangean rifting responsible for the initiation of ChinleDockum sedimentation: Insights from the Newark Supergroup and shared Late Triassic plate-scale tectonic events and geochronologies, Geol. Soc. Am. Abst. Prog., NE Sect., 48, https://doi.org/10.1130/abs/2016NE-271702, 2016.

Ikeda, M. and Tada, R.: Long period astronomical cycles from the Triassic to Jurassic bedded chert sequence (Inuyama, Japan); Ge- 
ologic evidences for the chaotic behavior of solar planets, Earth Planets Space, 65, 351-360, 2013.

Irmis, R. B., Mundil, R., Geissman, J. W., Kent, D. V., Olsen, P. E., and Whiteside, J. H.: New geochronologic constraints allow comparisons between Late Triassic biota and paleoenvironment from western and eastern North America, Geol. Soc. Am. Abst. Prog., 6, Paper 12-2, 2014.

Irmis, R. B., Olsen, P. E., Parker, W., Rasmussen, C., Mundil, R., and Whiteside, J. H.: Understanding Late Triassic low latitude terrestrial ecosystems: new insights from the Colorado Plateau Coring Project (CPCP), PP53A-1098 presented at 2017 Fall Meeting, AGU, New Orleans, L.A., 11-15 December 2017.

IUGS/ISC: International Chronostratigraphic Chart, v2017/02, International Commission on Stratigraphy, avaible at: http://www. stratigraphy.org/ICSchart/ChronostratChart2017-02.jpg (last access: September 2018), 2017.

Kent, D. V. and Irving, E.: Influence of inclination error in sedimentary rocks on the Triassic and Jurassic apparent pole wander path for North America and implications for Cordilleran tectonics, J. Geophys. Res., 115, B10103, https://doi.org/10.1029/2009JB007205, 2010.

Kent, D. V. and Olsen, P. E.: Astronomically tuned geomagnetic polarity time scale for the Late Triassic, J. Geophys. Res., 104, 12831-12841, 1999.

Kent, D. V. and Olsen, P. E.: Magnetic polarity stratigraphy and paleolatitude of the Triassic-Jurassic Blomidon Formation in the Fundy basin (Canada): implications for early Mesozoic tropical climate gradients, Earth Planet. Sc. Lett., 179, 311-324, 2000.

Kent, D. V. and Tauxe, L.: Corrected Late Triassic latitudes for continents adjacent to the North Atlantic, Science, 307, 240-244, 2005.

Kent, D. V. and Witte, W. K.: Slow apparent polar wander for North America in the Late Triassic and large Colorado Plateau rotation, Tectonics, 12, 291-300, 1993.

Kent, D. V, Santi Malnis, P., Colombi, C. E., Alcober, O. A., and Martínez, R. N.: Age constraints on the dispersal of dinosaurs in the Late Triassic from magnetochronology of the Los Colorados Formation (Argentina), P. Natl. Acad. Sci., 111, 79587963, 2014.

Kent, D. V., Olsen, P. E., and Muttoni, G.: Astrochronostratigraphic polarity time scale (APTS) for the Late Triassic and Early Jurassic from continental sediments and correlation with standard marine stages, Earth-Sci. Rev., 166, 153-180, 2017a.

Kent, D. V., Olsen, P. E., Mundil, R., Lepre, C. J., and CPCP Science Team: Testing the age calibration of the Newark-Hartford APTS by magnetostratigraphic correlation of $\mathrm{U}-\mathrm{Pb}$ zircon-dated tuffaceous beds in the Late Triassic Chinle Formation in core PFNP1A from the Petrified Forest National Park (Arizona, USA), PP44A-03 presented at 2017 Fall Meeting, AGU, New Orleans, L.A., 11-15 December, 2017b.

Kent, D. V., Olsen, P. E., Rasmussen, C., Lepre, C. J., Mundil, R., Irmis, R. B., Gehrels, G. E., Giesler, D., Geissman, J. W., and Parker, W. G.: Empirical evidence for stability of the 405 kyr Jupiter-Venus eccentricity cycle over hundreds of millions of years, P. Natl. Acad. Sci., 115, 6153-6158, 2018.

Knobbe, T. K. and Schaller, M. F.: A tight coupling between atmospheric $\mathrm{pCO}_{2}$ and sea-surface temperature in the Late Triassic, Geology, 46, 43-46, 2018.
Kozur, H. and Weems, R. E.: Conchostracan evidence for a late Rhaetian to early Hettangian age for the CAMP volcanic event in the Newark Supergroup, and a Sevatian (late Norian) age from the immediately underlying beds, Hallesches Jahrb. Geowiss., B27, 21-51, 2005.

Kuhn, T. K., Krull, E. S., Bowater, A., Grice, K., and Gleixner, G.: The occurrence of short chain n-alkanes with an even over odd predominance in higher plants and soils, Organic Geochemistry, 41, 88-95, 2010.

Larochelle, A. and Currie, K. L.: Paleomagnetic study of igneous rocks from the Manicouagan structure, Quebec, J. Geophys. Res., 72, 4163-4169, 1967.

Lawton, T. F.: Tectonic setting of Mesozoic sedimentary basins, Rocky Mountain region, United States, in: Mesozoic systems of the Rocky Mountain region, edited by: Caputo, M. V., Peterson, J. A., and Franczyk, K. J., USA: Rocky Mountain Section, SEPM (Society for Sedimentary Geology), 1-25, 1994.

Lindström, S., Irmis, R. B., Whiteside, J. H., Smith, N. S., Nesbitt, S. J., and Turner, A. H.: Palynology of the upper Chinle Formation in northern New Mexico, U.S.A.: Implications for biostratigraphy and terrestrial ecosystem change during the Late Triassic (Norian-Rhaetian), Review Palaeobot. and Palynol., 225, 106131, https://doi.org/10.1016/j.revpalbo.2015.11.006, 2016.

Litwin, R. J., Traverse, A., and Ash, S. R.: Preliminary palynological zonation of the Chinle Formation, southwestern USA, and its correlation to the Newark Supergroup (eastern USA), Rev. Palaeobot. Palynol., 68, 269-287, 1991.

Liu, L. and Gurnis, M.: Dynamic subsidence and uplift of the Colorado Plateau, Geology, 38, 663-666, 2010.

Long, R. A. and Murry, P. A.: Late Triassic (Carnian and Norian) Tetrapods from the Southwestern United States: Bulletin 4 (Vol. 4), New Mexico Mus. Nat. Hist. Sci., 4, 254 pp., 1995.

Lucas, S. G.: The Chinle Group: revised stratigraphy and biochronology of Upper Triassic nonmarine strata in the western United States, in: Aspects of Mesozoic Geology and Paleontology of the Colorado Plateau, edited by: Morales, M., Museum of Northern Arizona Bulletin 59, Flagstaff: Museum of Northern Arizona Press, 27-50, 1993.

Lucas, S. G.: Global Triassic tetrapod biostratigraphy and biochronology, Palaeogeo. Palaeoclimat. Palaeoeco., 143, 347384, 1998.

Lucas, S. G.: The Triassic timescale based on nonmarine tetrapod biostratigraphy and biochronology, Geol. Soc. Lond., Spec. Pub., 334, 447-500, 2010.

Lucas, S. G.: Chapter 10: Late Triassic terrestrial tetrapods: biostratigraphy, biochronology and biotic events, in: The Late Triassic World: Earth in a Time of Transition, edited by: Tanner, L. H., Topics in Geobiology, 351-405, 2018.

Lucas, S. G. and Schoch, R. R.: Triassic temnospondyl biostratigraphy, biochronology and correlation of the German Bundtsandstein and North American Moenkopi Formation, Lethaia, 35, 97 106, 2002.

Marsh, A. D., Rowe, T., Simonetti, A., Stockli, D., and Stockli, L. The age of the Kayenta Formation of northern Arizona: overcoming the challenges of dating fossil bone, J. Vert. Paleo. Prog. Abst., 2014, 178, 2014.

Martz, J. W. and Parker, W. G.: Revised lithostratigraphy of the Sonsela Member (Chinle Formation, Upper Triassic) in the south- 
ern part of Petrified Forest National Park, Arizona, PLoS One, 5, e9329, https://doi.org/10.1371/journal.pone.0009329, 2010.

Martz, J. W. and Parker, W. G.: Revised formulation of the Late Triassic Land Vertebrate "Faunachrons" of western North America: recommendations for codifying nascent systems of vertebrate biochronology, in: Terrestrial Depositional Systems: Deciphering Complexes Through Multiple Stratigraphic Methods, edited by: Ziegler, K. E. and Parker, W. G., 39-125, 2017.

Martz, J. W., Parker, W. G., Skinner, L., Raucci, J. J., Umhoefer, P., and Blakey, R. C.: Geologic map of Petrified Forest National Park, Arizona. Arizona Geological Survey, Contributed Map CR12-A, 1 map sheet, 1:50000 map scale, 2012.

Matthews, W. J., Hampson, G. J., Trudgill, B. D., and Underhill, J. R.: Controls on fluviolacustrine reservoir distribution and architecture in passive salt-diapir provinces: Insights from outcrop analogs, AAPG Bull., 91, 1367-1403, 2007.

McCall, A. M. and Kodama, K. P.: Anisotropy-based inclination correction for the Moenave Formation and Wingate Sandstone: implications for Colorado Plateau rotation, Front. Earth Sci., 2, 1-10, 2014.

McIntosh, J., Buhedma, H. M. A., Geissman, J. W., and CPCP Petrified Forest Science Team: Magnetic polarity stratigraphy and rock magnetic data from the continuous cored record of Triassic continental environmental change, the Colorado Plateau Coring Project, Am. Geophys. Union 2017, Fall Meeting Abstracts, paper PP53A-1100, available at: https://agu.confex.com/ agu/fm17/meetingapp.cgi/Paper/236192 (last access: September 2018), 2017.

Miller, C. S., Peterse, F., da Silva, A. C., Baranyi, V., Reichart, G. J., and Kürschner, W. M.: Astronomical age constraints and extinction mechanisms of the Late Triassic Carnian crisis, Scientific Reports, 7, https://doi.org/10.1038/s41598-017-02817-7, 2017.

Miller, G. L. and Ash, S. R.: The oldest freshwater decapod crustacean from the Triassic of Arizona, Palaeontology, 31, 272-279, 1988.

Molina-Garza, R. S., Geissman, J. W., Van der Voo, R., Lucas, S. G., and Hayden, S. N.: Paleomagnetism of the Moenkopi and Chinle Formations in central New Mexico: Implications for the North American apparent polar wander path and Triassic magnetostratigraphy, J. Geophys. Res., 96, 14239-14262, 1991.

Morales, M.: Terrestrial fauna and flora from the Triassic Moenkopi Formation of the southwestern United States, J. Ariz.-Nev. Acad. Sci., 22, 1-19, 1987.

Mori, H.: Dinosaurian faunas of the Cedar Mountain Formation with Detrital Zircon Ages for Three Stratigraphic Sections and the Relationship Between the Degree of Abrasion and U-Pb LAICP-MS Ages of Detrital Zircons, Provo, Utah, Brigham Young University, MSc. thesis, 102 pp., 2009.

Murry, P. A.: Stratigraphy of the Upper Triassic Petrified Forest Member (Chinle Formation) in Petrified Forest National Park, Arizona, USA, J. Geol. 98, 780-789, 1990.

Murry, P. A. and Long, R. A.: Geology and paleontology of the Chinle Formation, Petrified Forest National Park and vicinity, Arizona and a discussion of vertebrate fossils of the southwestern Upper Triassic, In, Lucas, S. G., and Hunt, A. P. (eds.) Dawn of the Age of Dinosaurs in the American Southwest, New Mexico Museum of Natural History, Albuquerque, New Mexico, 29-64, 1989.
Muttoni, G., Kent, D. V., Olsen, P. E., DiStefano, P., Lowrie, W., Bernasconi, S., and Hernandez, F. M.: Tethyan magnetostratigraphy from Pizzo Mondello (Sicily) and correlation to the Late Triassic Newark astrochronological polarity time scale, Geol. Soc. Am. Bull., 116, 1043-1058, 2004.

Muttoni, G., Mazza, M., Mosher, D., Katz, M. E., Kent, D. V., and Balini, M.: A Middle-Late Triassic (Ladinian-Rhaetian) carbon and oxygen isotope record from the Tethyan Ocean, Palaeogeo. Palaeoclim. Palaeoeco., 399, 246-259, 2014.

Ogg, J. G.: The Triassic Period, In, Gradstein, F. M., Ogg J, Smith A (eds.), A geologic time scale 2004, Cambridge University Press, Cambridge, 271-306, 2004.

Ogg, J. G.: Triassic, in: The Geological Time Scale 2012, edited by: Gradstein, F. M., Ogg, J. G., Schmitz, M., and Ogg, G., Elsevier, Amsterdam, 681-730, 2012.

Olsen, P., Geissman, J., Gehrels, G., Irmis, R., Kent, D., Martz, J., Mundil, R., and Parker, W.: The Colorado Plateau Coring Project (CPCP): Providing a precise numerical timescale for Triassic Earth system events and processes, Soc. Vert. Paleont., Prog. Abst., Berlin, Germany, 5-8 November 2014, 198-199, 2014a.

Olsen, P., Geissman, J., Gehrels, G., Irmis, R., Kent, D., Mundil, R., Parker, W., Sha, J. G., Garza, R. M., Kurschner, W., and Bachmann, G.: The Colorado Plateau Coring Project (CPCP): Chronostratigraphic Context for Triassic-Jurassic Earth System Events and Processes, 1st Symposium of IGCP 632 in the 4th International Palaeontological Congress, Mendoza, Argentina, 876, 2014b.

Olsen, P., Geissman, J., Gehrels, G., Irmis, R., Kent, D., Mundil, R., Parker, W., Sha, J., Roberto-Molina Garza, R.-M., Kuerschner, W., Bachmann, G., and Schaller, M.: The Colorado Plateau coring project (CPCP): exportable chronostratigraphic context for Triassic-Jurassic Earth System events and processes, Internat. Geol. Cong., Abstracts, 35; 35th international geological 65 congress, Cape Town, South Africa, 27 August-4 September 2016, 2016.

Olsen, P. E. and Kent, D. V.: Milankovitch climate forcing in the tropics of Pangea during the Late Triassic, Palaeogeo. Palaeoclim. Palaeoeco., 122, 1-26, 1996.

Olsen, P. E. and Kent, D. V.: Long-period Milankovitch cycles from the Late Triassic and Early Jurassic of eastern North America and their implications for the calibration of the early Mesozoic time scale and the long-term behavior of the planets, Philos. T. Roy. Soc. London A, 357, 1761-1787, 1999.

Olsen, P. E., Kent, D. V., and Geissman, J. W.: Climatic, Tectonic, and Biotic Evolution in Continental Cores: Colorado Plateau Coring Project: Workshop St. George, Utah, 13-16 November 2007, EOS, EOS, Trans. Am. Geophys. Union, 89, 2008.

Olsen, P. E., Kent, D. V., and Whiteside, H.: Implications of the Newark Supergroup-based astrochronology and geomagnetic polarity time scale (Newark-APTS) for the tempo and mode of the early diversification of the Dinosauria, Earth Environ. Sci. Trans. Roy. Soc. Edin., 101, 201-229, 2011.

Olsen, P. E., Kent, D. V., Geissman, J. W., Mundil, R., Gehrels, G. E., Irmis, R. B., Whiteside, J. H., Morgan, F., and Schaller, M. F.: Filling the Triassic geochronologic gap: a continuous cored record of continental environmental change in western North America. Abstract GP42A-10 presented at 2013 Fall Meeting, AGU, San Francisco, CA, 9-13 December 2013. 
Olsen, P. E., Geissman, J. W., Gehrels, G., Irmis, R. B., Kent, D. V., Mundil, R., Parker, W., Sha, J., Molina-Garza, R. S., Kuerschner, R., Bachmann, G. H., Schaller, M., Zakharova, N. V., and Colbert, M.: The Colorado Plateau Coring Project (CPCP): A continuous cored Record of Triassic continental environmental change in Western North America, AGU, 2014 Fall Meeting, Abstracts, Paper 11510, PP31C-1145, 2014.

Olsen, P. E., Reid, J. C., Taylor, K., Kent, D., and Whiteside, J. H.: Revised stratigraphy of Late Triassic age strata of the Dan River Basin (Virginia and North Carolina, USA) based on drill core and outcrop data, Southeastern Geology, 51, 1-31, 2015.

Olsen, P. E., Parker, W., Kuerschner, W., Huber, P., and Geissman, J.: Implications of the stratigraphic results of the Colorado Plateau Coring Project (CPCP): salt vs. plate tectonics vs. eustasy in the Late Triassic Chinle Formation, Internat. Geol. Cong., Abstracts 35; Paper number 4603, 35th International Geological Congress, Cape Town, South Africa, 27 August-4 September 2016, 2016.

Olsen, P. E., Mundil, R., and Kent, D. V.: CPCP Science Party, 2017, Milankovitch cyclicity in the paleotropical, fluvial, Late Triassic age strata recovered by the Colorado Plateau Coring Project (CPCP), PP53A-1099 presented at 2017 Fall Meeting, AGU, New Orleans, L.A., 11-15 December 2017.

Onoue, T., Sato, H., Yamashita, D., Ikehara, M., Yasukawa, K., Fujinaga, K., Kato, Y., and Matsuoka, A.: Bolide impact triggered the Late Triassic event in equatorial Panthalassa, Nature Sci. Rep., 6, 29609, https://doi.org/10.1038/srep29609, 2016.

Ouimette, M. A.: Preliminary report on the Pintado Point maar, Petrified Forest National Park, Nat. Park Ser., Paleont. Res. Abst., 2, 21, 1992.

Parker, W. G.: The stratigraphic distribution of major fossil localities in Petrified Forest National Park, Arizona, Mus. North. Ariz. Bull., 62, 46-61, 2006.

Parker, W. G. and Irmis, R. B.: Advances in Late Triassic vertebrate paleontology based on new material from Petrified Forest National Park, Arizona, New Mexico Mus. Nat. Hist. Sci. Bull., 29, 45-58, 2005.

Parker, W. G. and Martz, J. W.: The Late Triassic (Norian) Adamanian-Revueltian tetrapod faunal transition in the Chinle Formation of Petrified Forest National Park, Arizona, Earth Environ. Sci. Trans. Roy. Soc. Edin., 101, 231-260, 2011.

Parker, W. G., Ash, S. R., and Irmis, R. B. (Eds.): A Century of Research at Petrified Forest National Park: Geology and Paleontology, Mus. North. Ariz. Bull., 62, 187 pp., 2006a.

Parker, W. G., Irmis, R. B., and Nesbitt, S. J.: Review of the Late Triassic dinosaur record from Petrified Forest National Park, Arizona, Mus. North. Ariz. Bull., 62, 160-161, $2006 \mathrm{~b}$.

Ramezani, J., Bowring, S. A., Pringle, M. S., Winslow III, F. D., and Rasbury, E. T.: The Manicouagan impact melt rock: A proposed standard for the intercalibration of U-Pb and 40Ar/39Ar isotopic systems, Geochim. Cosmochim. Acta Supp., 69, A321, 2005.

Ramezani, J., Hoke, G. D., Fastovsky, D. E., Bowring, S. A., Therrien, F., Dworkin, S. I., Atchley, S. C., and Nordt, L. C.: Highprecision $\mathrm{U}-\mathrm{Pb}$ zircon geochronology of the Late Triassic Chinle Formation, Petrified Forest National Park (Arizona, USA): Temporal constraints on the early evolution of dinosaurs, Geol. Soc. Am. Bull., 123, 2142-2159, 2011.

Ramezani, J., Fastovsky, D. E., and Bowring, S. A.: Revised chronostratigraphy of the lower Chinle Formation strata in Ari- zona and New Mexico (USA): high-precision U-Pb geochronological constraints on the Late Triassic evolution of dinosaurs, Am. J. Sci., 314, 981-1008, 2014.

Rasmussen, C., Mundil, R., Irmis, R. B., Keller, C. B., Giesler, D., and Gehrels, G. E.: U-Pb Geochronology of non-marine Upper Triassic strata of the Colorado Plateau (western North America): implications for stratigraphic correlation and paleoenvironmental reconstruction, Am. Geophys. Union 2017, Fall Meeting Abst., available at: https://agu.confex.com/agu/fm17/ meetingapp.cgi/Paper/266123 (last access: September 2018), 2017.

Rauzi, S. L.: Permian Salt in the Holbrook Basin, Arizona, Ariz. Geol. Sur. Open File Rept., OFR-00-03, 1-20, 2000,

Reichgelt, T., Parker, W. G., Martz, J. W., Conran, J. G., van Konijnenburg-van Cittert, J. H. A., and Kürschner, W. M.: The palynology of the Sonsela Member (Late Triassic, Norian) at Petrified Forest National Park, Arizona, USA, Rev. Palaeobot. Palynol., 189, 18-28, 2013.

Riggs, N. R., Lehman, T. M., Gehrels, G. E., and Dickinson, W. R.: Detrital zircon link between headwaters and terminus of the Upper Triassic Chinle-Dockum paleoriver system, Science, 273, 97-100, 1996.

Riggs, N. R., Ash, S. R., Barth, A. P., Gehrels, G. E., and Wooden, J. L.: Isotopic age of the Black Forest Bed, Petrified Forest Member, Chinle Formation, Arizona: an example of dating a continental sandstone, Geol. Soc. Am. Bull., 115, 1315-1323, 2003.

Riggs, N. R., Reynolds, S. J., Lindner, P. J., Howell, E. R., Barth, A. P., Parker, W. G., and Walker, J. D.: The Early Mesozoic Cordilleran arc and Late Triassic paleotopography: The detrital record in Upper Triassic sedimentary successions on and off the Colorado Plateau, Geosphere, 9, 602-613, 2013.

Riggs, N. R., Oberling, Z. A., Howell, E. R., Parker, W. G., Barth, A. P., Cecil, M. R., and Martz, J. W.: Sources of volcanic detritus in the basal Chinle Formation, southwestern Laurentia, and implications for the Early Mesozoic magmatic arc, Geosphere, 12, 439-463, 2016.

Ruffell, A., Simms, M. J., and Wignall, P. B.: The Carnian Humid Episode of the late Triassic: a review, Geol. Mag., 153, 271-284, 2016.

Schultz, L. G.: Clay minerals in Triassic rocks of the Colorado Plateau, U.S. Geol. Sur. Bull. 1147-C, 71 pp., 1963.

Schwab, K. W., Miller, H. W., and Smith, M. A.: Source-rock potential of the Lower Permian Supai Formation in the Blackstone Exploration Company Rocking Chair Ranch No. 4 well, Navajo County, Arizona, Search and Discovery, Article \#80601, 21 pp., 2017.

Scott, R. A.: Aspects of the Palynology of the Chinle Formation (Upper Triassic), Colorado Plateau, Arizona, Utah and New Mexico, U.S. Geol. Surv. Open-File Rep. 82-937, 19 pp., 1982.

Schaller, M. F., Wright, J. D., and Kent, D. V.: Atmospheric $p \mathrm{CO}_{2}$ perturbations associated with the Central Atlantic magmatic province, Science, 331, 1404-1409, 2011.

Schaller, M. F., Wright, J. D., and Kent, D. V.: A 30 Myr record of Late Triassic atmospheric $p \mathrm{CO}_{2}$ variation reflects a fundamental control of the carbon cycle by changes in continental weathering, Geol. Soc. Am. Bull., 127, 661-671, 2015.

Schaller, M., Pettitt, E., and Knobbe, T.: A potential new proxy for paleo-atmospheric $\mathrm{pO}_{2}$ from soil carbonate-hosted fluid inclusions applied to pristine Chinle soils from the Petrified Forest 
1A core, PP44A-05 presented at 2017 Fall Meeting, AGU, New Orleans, L.A., 11-15 December 2017.

Shoemaker, E. M., Case, J. E., and Elston, D. P.: Salt anticlines of the Paradox Basin. Guidebook to the Geology of the Paradox Basin, Ninth Annual Field Conference, 1958, 39-59, 1958.

Sigloch, K. and Mihalynuk, M. G.: Intra-oceanic subduction shaped the assembly of Cordilleran North America, Nature, 496, 50-57, 2013.

Sigloch, K. and Mihalynuk, M. G.: Mantle and geological evidence for a Late Jurassic-Cretaceous suture spanning North America, GSA Bull., 129, 1489-1520, 2017.

Stanley Jr., G. D.: Early history of scleractinian corals and its geological consequences, Geology, 9, 507-511, 1981.

Steiner, M. B.: Rotation of the Colorado Plateau, Tectonics, 5, 649$660,1986$.

Steiner, M. B. and Lucas, S. G.: Paleomagnetism of the Late Triassic Petrified Forest Formation, Chinle Group, western United States: further evidence of "large" rotation of the Colorado Plateau, J. Geophys. Res., 105, 25791-25808, 2000.

Stone, A., Brady, K., Noren, A., Olsen, P., Mundil, R., Kent, D., Irmis, R., Gehrels, G., Giesler, D., Lepre, C., Geissman, J., Haque, Z., and Rasmussen, C.: CPCP, https://doi.org/10.17605/OSF.IO/5VD8U, 2016.

Suarez, C. A., Knobbe, T. K., Crowley, J. L., Kirkland, J. I., and Milner, A. R.: A chronostratigraphic assessment of the Moenave Formation, USA using C-isotope chemostratigraphy and detrital zircon geochronology: Implications for the terrestrial end Triassic extinction, Earth Planet. Sc. Lett., 475, 83-93, 2017.

Tanner, L. H. and Lucas, S. J., The Triassic-Jurassic strata of the Newark Basin, USA: A complete and accurate astronomicallytuned timescale? Stratigraphy, 12, 47-65, 2015.

Tanner, L. H., Lucas, S. G., and Chapman, M. G.: Assessing the record and causes of Late Triassic extinctions, Earth-Sci. Rev., 65, 103-139, 2004.

Therrien, F. and Fastovsky, D. E.: Paleoenvironments of Early Theropods, Chinle Formation (Late Triassic), Petrified Forest National Park, Arizona, Palaios, 15, 194-211, 2000.

Trendell, A. M., Atchley, S. C., and Nordt, L. C.: Facies analysis of a probable large-fluvial-fan depositional system: the Upper Triassic Chinle Formation at Petrified Forest National Park, Arizona, USA, J. Sed. Res., 83, 873-895, 2013.
Trotter, J. A., Williams, I. S., Nicora, A., Mazza, M., and Rigo, M.: Long-term cycles of Triassic climate change: A new $\delta^{18} \mathrm{O}$ record from conodont apatite, Earth Planet. Sc. Lett., 415, 165174, https://doi.org/10.1016/j.epsl.2015.01.038, 2016.

Trudgill, B. D.: Evolution of salt structures in the northern Paradox Basin: controls on evaporite deposition, salt wall growth and supra-salt stratigraphic architecture, Basin Res., 23, 208-238, https://doi.org/10.1111/j.1365-2117.2010.00478.x, 2011.

Trujillo, K. C., Foster, J. R., Hunt-Foster, R. K., and Chamberlain, K. R.: A U/Pb age for the Mygatt-Moore Quarry, Upper Jurassic Morrison Formation, Mesa County, Colorado, Volumina Jurassica, 12, 107-114, 2014.

Walker, J. D., Geissman, J. W., Bowring, S. A., and Babcock, L. E.: The Geological Society of America Geologic Time Scale, Geol. Soc. Am. Bull., 25, 259-272, https://doi.org/10.1130/B30712.1, 2013.

White, J. D. L.: Depositional architecture of a maar-pitted playa: sedimentation in the Hopi Buttes volcanic field, northeastern Arizona, U.S.A., Sed. Geol., 67, 55-84, 1990.

Whiteside, J. H., Olsen, P. E., Eglinton, T. I., Brookfield, M. E., and Sambrotto, R. N.: Compound-specific carbon isotopes from Earth's largest flood basalt province directly link eruptions to the end-Triassic mass extinction, P. Natl. Acad. Sci., 107, 6721$6725,2010$.

Whiteside, J. H., Grogan, D. S., Olsen, P. E., and Kent, D. V.: Climatically driven biogeographic provinces of Late Triassic tropical Pangea, P. Natl. Acad. Sci., 108, 8972-8977, 2011.

Whiteside, J. H., Lindström, S., Irmis, R. B., Glasspool, I. J., Schaller, M. F., Dunlaveyh, M., Nesbitt, S. J., Smith, N. D., and Turner, A. H.: Extreme ecosystem instability suppressed tropical dinosaur dominance for 30 million years, P. Natl. Acad. Sci., 112, 7909-7913, 2015.

Woody, D. T.: Revised stratigraphy of the lower Chinle Formation (Upper Triassic) of Petrified Forest National Park, Arizona, Mus. North. Ariz. Bull., 62, 17-45, 2006.

Zeigler, K. E., Parker, W. G., and Martz, J. W.: The lower Chinle Formation (Late Triassic) at Petrified Forest National Park Southwestern U.S.A.: a case study in magnetostratigraphic correlations, in: Terrestrial Depositional Systems: Deciphering Complexes Through Multiple Stratigraphic Methods, edited by: Ziegler, K. E. and Parker, W. G., 237-277, 2017. 